Review

\title{
Superposed Natural Hazards and Pandemics: Breaking Dams, Floods, and COVID-19
}

\author{
Mohammad Amin Hariri-Ardebili ${ }^{1,2, *(D)}$ and Upmanu Lall ${ }^{3,4}$ (D) \\ 1 Department of Civil Environmental and Architectural Engineering, University of Colorado, \\ Boulder, CO 80309, USA \\ 2 College of Computer, Mathematical and Natural Sciences, University of Maryland, \\ College Park, MD 20742, USA \\ 3 Department of Earth and Environmental Engineering, Columbia University, New York, NY 10027, USA; \\ ula2@columbia.edu \\ 4 Columbia Water Center, Earth Institute, Columbia University, New York, NY 10027, USA \\ * Correspondence: mohammad.haririardebili@colorado.edu; Tel.: +1-303-990-2451
}

Citation: Hariri-Ardebili, M.A.; Lall, U. Superposed Natural Hazards and Pandemics: Breaking Dams, Floods, and COVID-19. Sustainability 2021, 13 8713. https://doi.org/10.3390/ su13168713

Academic Editor: Marc A. Rosen

Received: 27 April 2021

Accepted: 27 July 2021

Published: 4 August 2021

Publisher's Note: MDPI stays neutral with regard to jurisdictional claims in published maps and institutional affiliations.

Copyright: (c) 2021 by the authors. Licensee MDPI, Basel, Switzerland. This article is an open access article distributed under the terms and conditions of the Creative Commons Attribution (CC BY) license (https:/ / creativecommons.org/licenses/by/ $4.0 /)$.

\begin{abstract}
Within the engineering domain, safety issues are often related to engineering design and typically exclude factors such as epidemics, famine, and disease. This article provides a perspective on the reciprocal relationship and interaction between a natural hazard and a simultaneous pandemic outbreak and discusses how a catastrophic dam break, combined with the ongoing COVID-19 pandemic, poses a risk to human life. The paper uses grey- and peer-reviewed literature to support the discussion and reviews fundamentals of dam safety management, potential loss of life due to a dam break, and the recent evolution in dam risk analysis to account for the COVID-19 outbreak. Conventional risk reduction recommendations, such as quick evacuation and sheltering in communal centers, are revisited in the presence of a pandemic when social distancing is recommended. This perspective manuscript aims to provide insight into the multi-hazard risk problem resulting from a concurring natural hazard and global pandemic.
\end{abstract}

Keywords: natural hazard; pandemic; dam break; flood; risk management

\section{Introduction}

Human life is affected by a variety of natural hazards, e.g., earthquakes, floods, tsunamis, hurricanes, etc. [1]. Hazard analysis refers to a process of assessing hazards that may arise from a system or its environment, documenting their unwanted consequences, and analyzing their potential causes [2]. Depending on its source, a natural hazard may be classified as: geologic (e.g., earthquake), climatic (e.g., flood), or biological (e.g., disease epidemic). A catastrophic natural hazard causes devastating consequences to a large number of people. Hazard, by itself, cannot be avoided. However, it may poses a risk:

$$
\text { Risk }=(\text { Hazard } \times \text { Vulnerability } \times \text { Exposure }) / \text { Capacity }
$$

Traditionally, dam safety risk management frameworks account for the probability of various natural hazards and their impacts on potential flooding, loss of life (LoL), and property damage [3]. These analyses typically deal with scenarios of individual natural disasters. A question that arises is: What happens if a pandemic and natural hazard occur simultaneously? Such a scenario could cause mass casualties and widespread infrastructural devastation. While any natural disaster in isolation is horrific enough, one occurring during a pandemic would place a nightmarish gantlet of novel obstacles between first responders and saving the lives of the afflicted [4]. In this paper, the terms compound-hazard and multi-hazard will be used to characterize the situation that represents the confluence of multiple hazards, a topic that has recently seen considerable scientific interest, since past analytical frameworks have not considered such scenarios in depth for engineering design 
and system management. Although there are many and sometimes diverse definitions for these terms $[5,6]$, we define compound-hazard as more than one hazard resulting from the same source (e.g., heavy rainfall that leads to flooding and a nuclear emergency notification), while multi-hazard is a combination of two or more hazards from various sources coinciding accidentally or, more often, following one another with damaging force [7] (e.g., flood and earthquake or flood and pandemic).

The novel coronavirus pandemic that emerged in December 2019 from Wuhan, China, known as COVID-19 [8], is the most recent biological hazard with a persistent global outbreak. COVID-19 is a zoonotic disease with a low to moderate mortality rate. Its persistence and the societal response to it creates a potential juxtaposition with other natural hazards with a high probability. Person-to-person transmission may occur through droplets or direct contact [9], and therefore isolation of cases and contact tracing are essential to controlling COVID-19 outbreaks, though the probability of successfully controlling an outbreak decreases as the number of initial cases increases [10].

Pandemics behave differently than other hazards, requiring unique monitoring systems that deal with complex sociomedical data and emerging contexts [11]. Additionally, the expected, and often required, response by individuals in times of such a crisis is very different. The Sendai Framework for Disaster Risk Reduction (SFDRR) 2015-2030 [12] recognizes the connection between health risks and hazards, including those that are geophysical, hydrological, climatological, and meteorological [13]. While it stresses risk reduction considerations for biological hazards, it does not distinguish how these considerations are similar or different from those of natural hazards.

In this paper, dam safety management, potential loss of life due to a dam break, and the recent evolution in dam risk analysis to include a simultaneous COVID-19 outbreak are reviewed. Some low-probability, high-hazard scenarios are introduced, and the conventional risk reduction recommendations (e.g., evacuation and sheltering in communal centers) are revisited in the presence of a pandemic in which social distancing is a mitigating factor [14]. Dam safety risk analysis typically considers climatic (i.e., rainfall and over-topping) and/or seismic factors and exemplifies a situation where an infrastructure is designed in the context of a specific natural hazard but without the consideration of other factors, such as pandemics that may be at play during the event of failure where relief and recovery are needed.

While the connection of COVID-19 and environmental sciences can be discussed from many different and sometime diverse aspects [15], here, we review how a discrete hazard such as a dam failure overlaid on a pandemic could be managed through an integrated cycle of preparation, response, and recovery [16]. The importance of such an interdisciplinary study has been addressed already [17]. The interaction between pandemic and natural hazards is not well understood, and there are only a few peer-reviewed studies. For example, Mishra et al. [18] studied the simultaneous effects of droughts and pandemics on global food supply chains. According to their findings, when a community experiences both the hazards together, the uncertainties are increased and the disruptions are compounded, which eventually lead to severe economic stress and food insecurity.

Figure 1 illustrates some of the key aspects of superposed natural hazards and pandemics that will be discussed in this paper. Our focus will be on failure of (aging) dams and also the floods during dam break and other natural hazards. The interaction of natural hazards with pandemic will be discussed, and the extra potential risk due to multi-hazard will be highlighted. This paper will not cover some other influencing factors, e.g., complex emergencies [19]. We believe that anyone in any position should contribute (to the extent possible) to improve the knowledge related to COVID-19 outbreak, and as Haas [20] truly said: "Risk analysts and risk analysis researchers should not be shy about contributing our skills to important policy developments during this crisis." 


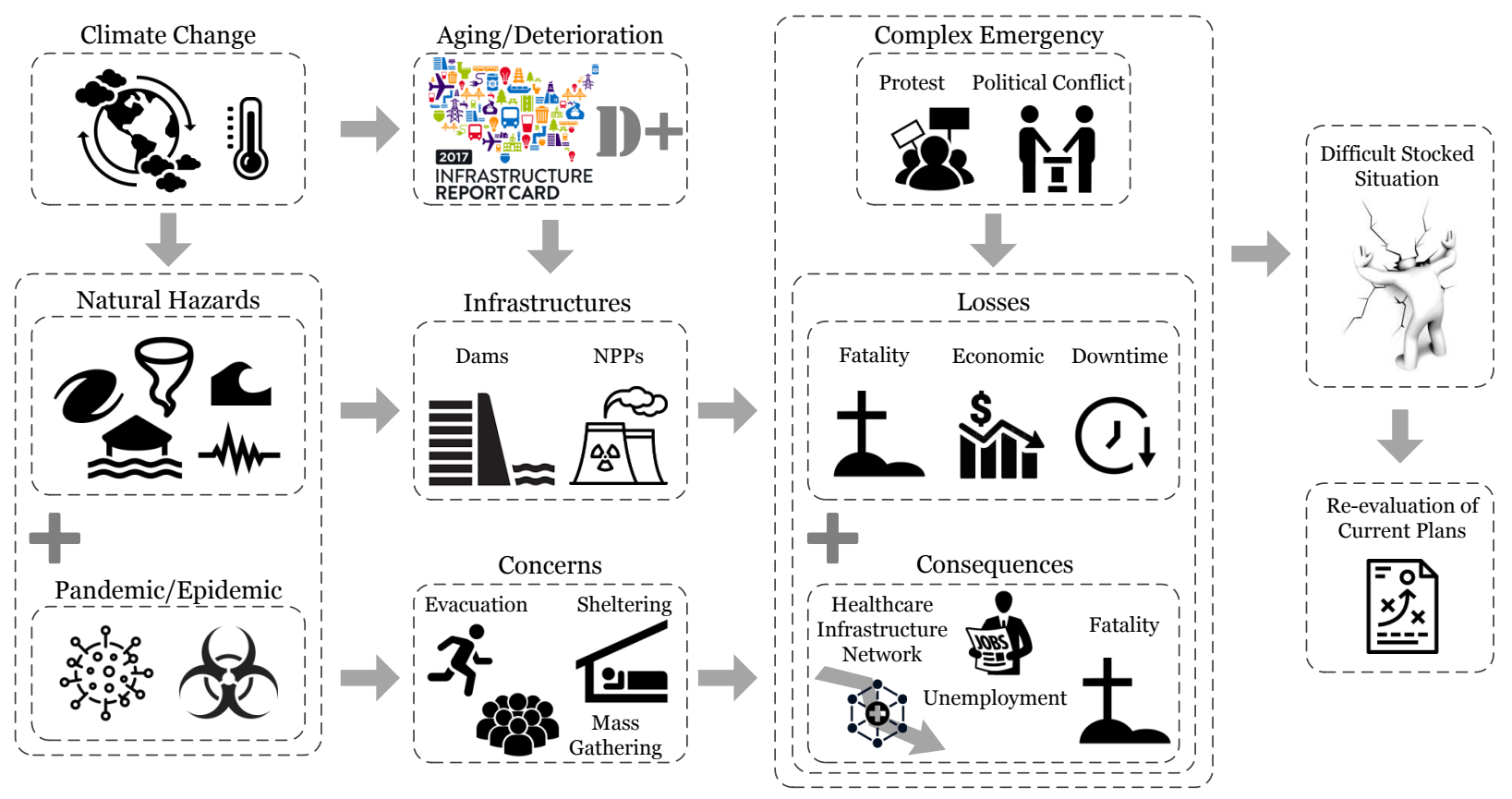

Figure 1. A big picture illustrating superposed natural hazards and pandemics.

\section{Dams and Hydropower in the Era of COVID-19}

\subsection{Hydropower and COVID-19}

Hydropower is the second largest source of renewable energy in the United States as of 2020 (behind wind power), Figure 2a. Annual changes in hydroelectric generation primarily result from variations in precipitation patterns and water runoff. Both hydroelectric and wind generation follow seasonal patterns, with the former typically greatest in the spring when precipitation and melting snowpack increase water runoff. Most hydroelectricity is produced at large, federally-built dams, many of which are in the Western United States with considerable potential natural hazards (e.g., earthquakes, wildfires). In 2019, the U.S. generated about 274 billion $\mathrm{kWh}$ of conventional hydroelectricity ( $6.6 \%$ of total U.S. utilityscale electricity generation) [21]. Distribution of hydroelectricity generation by state is shown in Figure 2b.

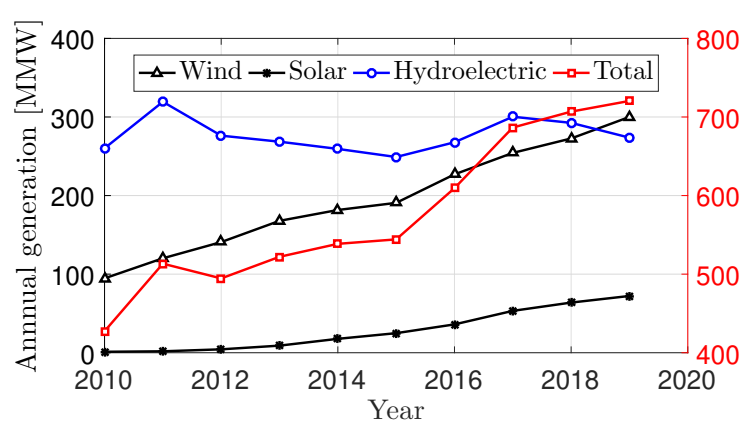

(a) Annual electricity generation

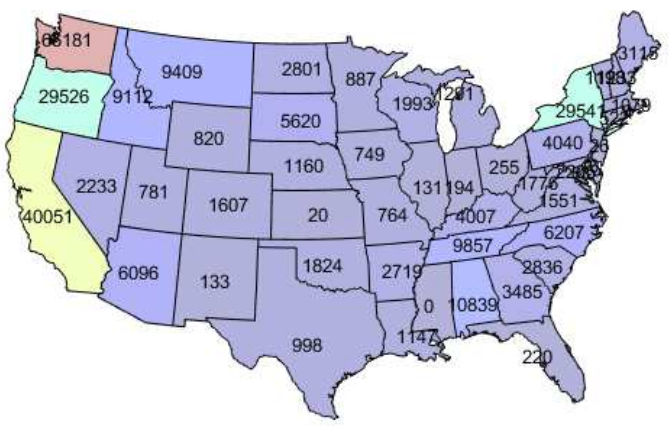

(b) Hydroelectricity generation in 2019 (billion kWh)

Figure 2. Comparison of hydropower and other renewable energy sources in the U.S. including the hydroelectricity generation by state [21].

The COVID-19 pandemic has already wreaked havoc on general society and the economy. According to Eddie Rich, CEO of the International Hydropower Association (IHA), COVID-19 has had clear impacts on the hydropower industry, such as hampering 
supply chains and delaying projects [22]. Despite this, while the oil and gas industries saw their prices significantly decrease and lobbyists tried to protect the price of coal, the hydropower industry proved to be a reliable energy source.

Hydropower was at the center of (perhaps) the largest ever electricity experiment in the world. Prime Minister Narendra Modi of India had urged all countrymen to switch off their lights for nine minutes at 9:00 p.m. on 5 April 2020 and light candles as a sign of solidarity in the fight against COVID-19. This resulted in an almost 31,000 MW-reduction of power consumption in about half an hour (9:00 p.m. $\pm 15 \mathrm{~min}$ ). During that period, hydropower generation was quickly reduced from about 25,500 MW to only 8000 MW to match the reduction in demand. Similarly, hydropower's unique flexibility allowed stations to ramp up again within seconds to meet the demand as it increased, a feature that is unavailable with traditional energy resources [23].

\subsection{Dam Failure: Case Histories and Recent Events}

Dams, a main component of hydropower systems, provide significant societal benefits, but they also pose significant risks. Dam failures, although rare, can be catastrophic and may cause immense damage and loss of life. There are over 90,580 operational dams across the U.S. [2]. Based on classifications from the Federal Emergency Management Agency (FEMA), there were 15,500 high-hazard dams in 2016, and the number of those considered deficient high-hazard climbed to about 2200 in 2017 [24]. According to the American Society of Civil Engineers (ACSE), the average age of dams in the U.S. in 2020 is over 59 years old.

The National Performance of Dams Program (NPDP) developed a database for U.S. dam failures between 1848 and 2017 [25]. According to this database, there were 1645 reported dam failures during this period, Figure 3a, of which only 99 cases are from dams over $15 \mathrm{~m}$ high, a ratio that is consistent with dam height distributions in the U.S. Overall, 64 of these failures resulted in an estimated 3500 fatalities, Figure 3b [26]. Historical U.S. dam failures with more than 25 fatalities are listed below [27]:

- Mill River Dam (Massachusetts, 1874), Age at failure: 9, Lives lost: 138

- South Fork Dam (Pennsylvania, 1889), Age at failure: 36, Lives lost: 2209

- Walnut Grove Dam (Arizona, 1890), Age at failure: 2, Lives lost: 70-100

- Austin Dam (Pennsylvania, 1911), Age at failure: 2, Lives lost: 78

- Lower Otay (California, 1916), Age at failure: 19, Lives lost: 30

- St. Francis Dam (California, 1928), Age at failure: 2, Lives lost: 420

- Buffalo Creek Coal Waste Dam (West Virginia, 1972), Age at failure: 0, Lives lost: 125

- Canyon Lake Dam (South Dakota, 1972), Age at failure: 39, Lives lost: 474 total

- Laurel Run Dam (Pennsylvania, 1977), Age at failure: 63, Lives lost: 40

- Kelly Barnes Dam (Georgia, 1977), Age at failure: 78, Lives lost: 39

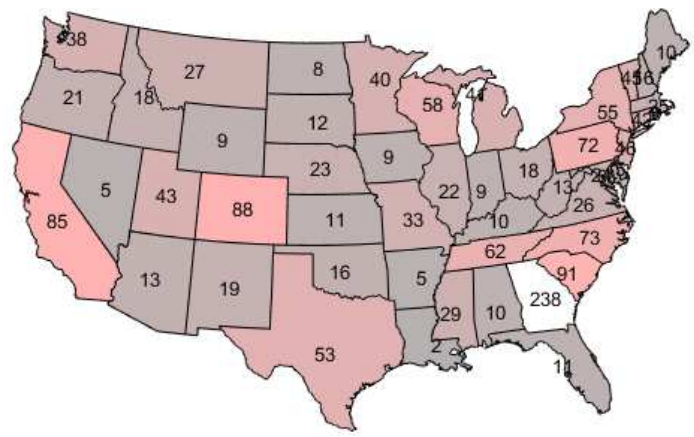

(a) Dam failures (1848 to 2017)
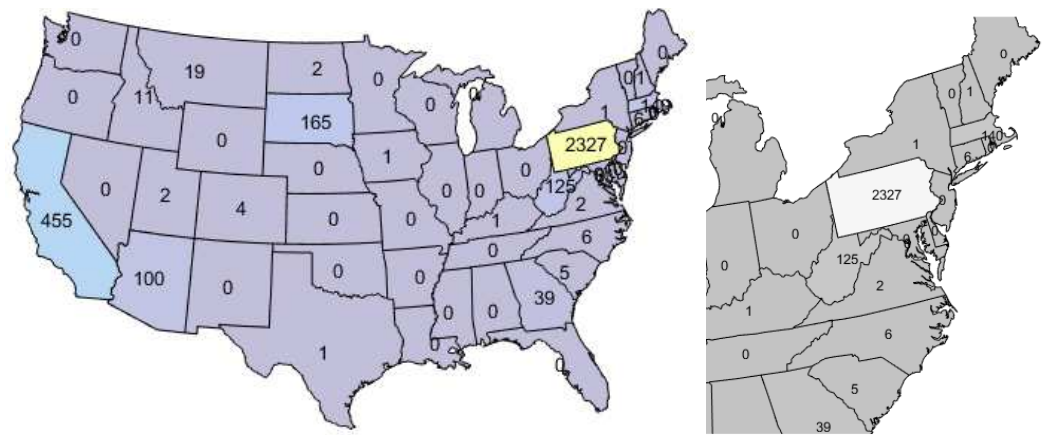

(b) Dam failure fatalities (1960-2019)

Figure 3. Dam failures and the associated fatalities in the U.S.

Further readings about statistical analyses of dam failures can be found in [28]. At the international level, the ICOLD [29]'s recent draft of the incident database provides useful 
information about important parameters in dam failure [30]. Recently, there have been major dam failures across the U.S., including the 2017 Oroville Dam's spillway incident [31] which led to the evacuation of over 200,000 people.

With the COVID-19 outbreak upon us, a dam failure due to flooding or a major earthquake could only make matters worse. On 19 May 2020, following heavy rains, the Edenville Dam breached, and the Sanford Dam downstream overflowed, causing a major flood in Midland County Michigan. While experts described this as a 500-year event, Michigan's governor estimated that downtown Midland could wind up under approximately $9 \mathrm{ft}$ of water. Water in the Tittabawassee River rose to about $34.4 \mathrm{ft}$, beating the previous record of $33.9 \mathrm{ft}$ set during flooding in 1986. Subsequently, the National Weather Service (NWS) urged anyone near the river to seek higher ground following failures at the Edenville Dam (about 140 miles north of Detroit) and the Sanford Dam (about seven miles downriver). Figure 4 illustrates the simulated flood using HEC-RAS 2D [32]. The dam breach parameters were estimated based on videos published on social media. Spreading water upstream is consistent with NASA Earth Observatory Satellite images, given assumptions made in the simulation [33]. Dam discharge was calibrated using the downstream gauge rating of the Midland-area dam.

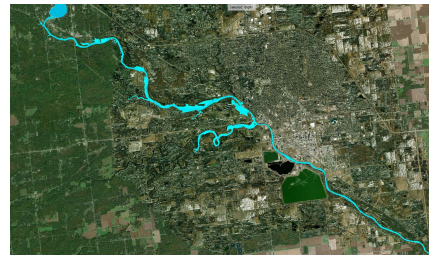

(a) 15 May 2020

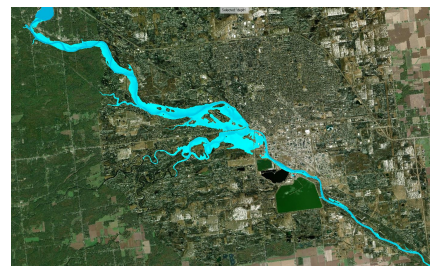

(e) 19 May 2020

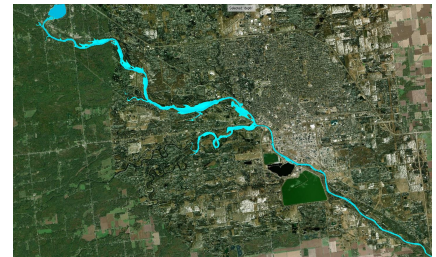

(b) 16 May 2020

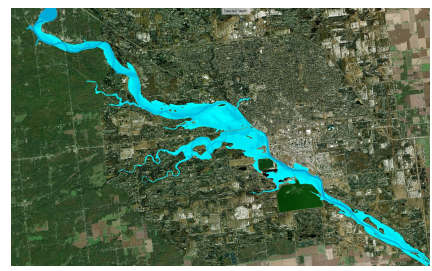

(f) 20 May 2020

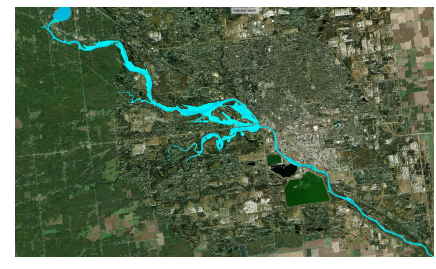

(c) 17 May 2020

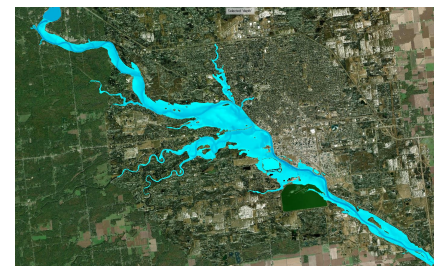

(g) 21 May 2020

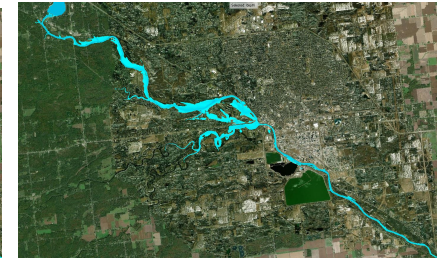

(d) 18 May 2020

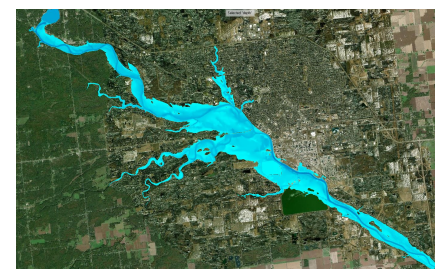

(h) 22 May 2020

Figure 4. Simulated flood for nine days in the Midland; Simulation by F. Zorofchi, 27 May 2020.

Sanford Dam, Figure 5a, is a private, concrete dam completed in 1925 that is $36 \mathrm{ft}$ tall with a storage capacity of 15,000 acre-feet. It is categorized as high hazard by the National Inventory of Dams (NID) [34] and is regulated by the Federal Energy Regulatory Commission (FERC). By contrast, Edenville Dam, Figure $5 b$, is a private, earthfill dam completed in 1924 that is $54 \mathrm{ft}$ tall with a storage capacity of 66,200 acre-feet. This dam is also categorized as high hazard by the NID [34] and is regulated by the FERC.

The Edenville Dam levee break caused more water to be released into the Tittabawassee River, which feeds into Sanford Lake. The floodwaters quickly overran Sanford Dam, washing out its fuse plug and escaping around the sides of the dam, but they did not cause structural collapse. In 2018, the FERC revoked Boyce Hydro's license to operate Edenville Dam due to non-compliance issues, including spillway capacity and the inability to pass the most severe flood reasonably. That year, the state rated the dam to be in unsatisfactory condition.

These catastrophic dam failures forced the evacuation of 11,000 people in central Michigan, including patients in the Midland Hospital and residents of Sanford, Edenville and other nearby communities. During the evacuation, officials cautioned residents to maintain physical distancing due to the COVID-19 pandemic. It was fortunate that both dams had emergency action plans (EAPs) in place, Figure $5 c$, to facilitate the evacuation 
and reduce crisis-related confusion; however, the majority of high-hazard dams do not have such plans established. The cost of dam breach inundation maps is a major impediment towards developing EAPs for high- or significant-hazard dams. This level of preparedness (See Section 3.2) also helps to ensure fast and safe recovery after any natural disaster and paves the road for pandemic-resilient communities [35].

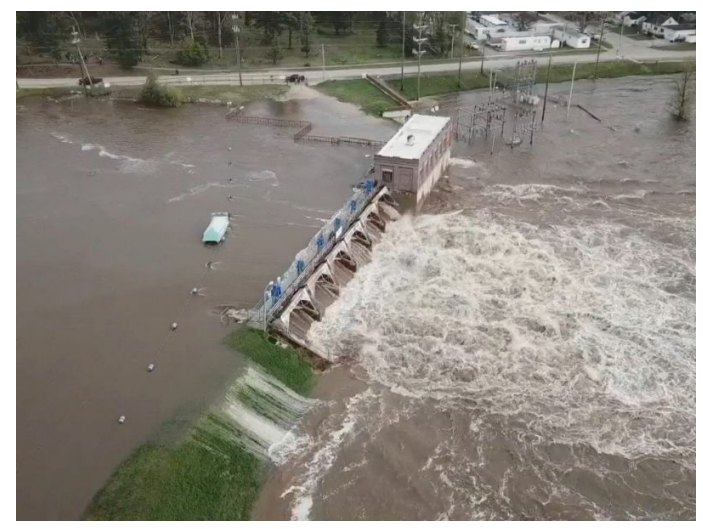

(a) Sanford Dam failure; photo from NRP; 20 May 2020

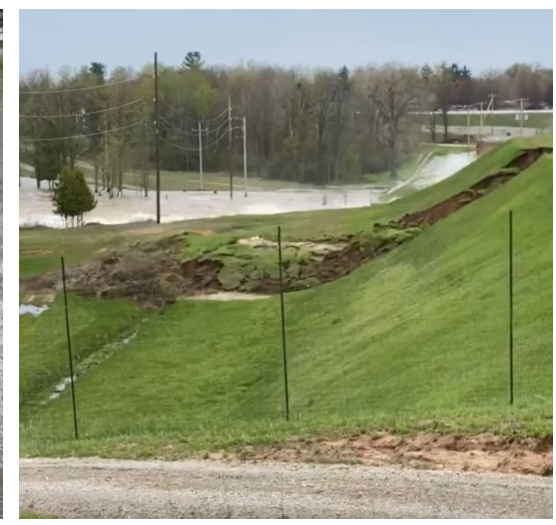

(b) Edenville Dam failure; photo from AGU; 21 May 2020

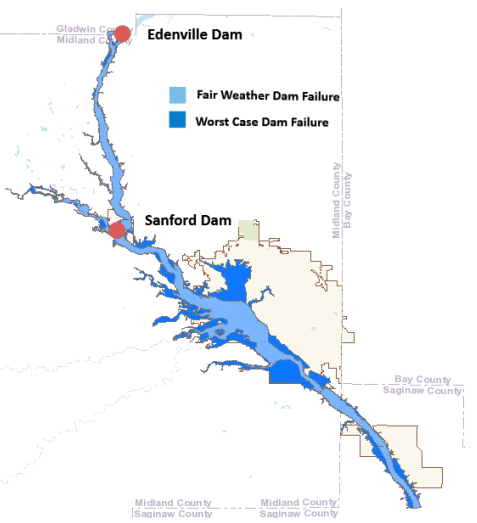

(c) Emergency action plan

Figure 5. Michigan dam failure on 19 May 2020.

Michigan has been a national hot spot for COVID-19, with more than 55,000 cases and 5300 deaths (as of 30 May 2020), although Midland County has only reported about 80 cases and under 10 deaths (as of 20 May 2020). Still, Midland residents were advised to take precautions, and schools, set up as shelters, spaced emergency cots in adherence with social distancing guidelines [36].

For high-hazard dams, two primary dam breach approaches are recommended: eventbased and risk-based. The former is a deterministic method of analysis based on specific precipitation and non-precipitation events and downstream inundation mapping [37]. For this, two maps are usually developed: fair-weather dam failure (also known as sunny day failure) and worst-case dam failure (also known as rainy day failure). Fair-weather failure is a non-hydrologic breach that is analyzed by establishing an initial reservoir level and commencing the analysis without additional inflow from a storm event. It is typically used to model piping failures for hydrologic, geologic, structural, seismic, and humaninfluenced failure modes. On the other hand, hydrologic failure events use extreme flood events subjected to the Probable Maximum Flood (PMF) for high-hazard dams. Such maps are shown in Figure $5 c$ for two Michigan dams.

\subsection{Pandemic and Flooding: Worldwide Experience}

Let us now consider the multi-hazard occurrence of flooding and a pandemic outbreak as well as their potential interactions. Figure 6 provides an overall picture of the distribution of global disasters and their associated loss of life. The data is normalized by millions of people to provide a clearer vision for different countries. The average death per capita is higher in African countries, both for flooding and pandemic events, though the loss of life associated with pandemics is higher than with flooding. Finally, while there is no clear relationship between a pandemic event and its losses, such a correlation can be partially observed for flooding. There exist some documents which discuss the floods and pandemic double hazard problem [38].

Some of the less developed regions and cities, specifically in Africa, face multi-risk problems that often overlap: local public health hazards, poor air quality, water and industrial pollution, and natural disasters [39]. The 2014 cholera pandemic in Ghana 
and the 2015 flood disaster in its capital, Accra, are major recent cases. Flooding and cholera outbreaks often have greater negative impacts when accompanied by inadequate provisioning of services, e.g., drinking water, sanitation, garbage collection, low hygiene, and human settlement on wetlands. There were 211 deaths - a fatality rate of $0.8 \%$. The 2015 flood was the worst event to hit the Accra metropolitan area, and three days of consecutive rains brought a large amount of water to an already oversaturated ground from previous rains. The flood resulted in about 200 lives lost and affected over 46,000 people. Floods intensify the cycle of individual and household poverty, including the spread of diseases (e.g., diarrhea and cholera) [39].

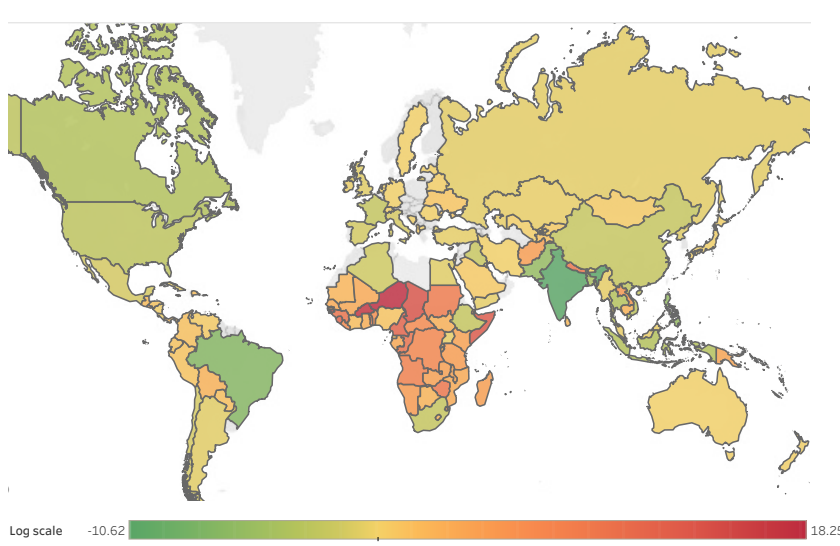

(a) Average death per capita; Epidemic

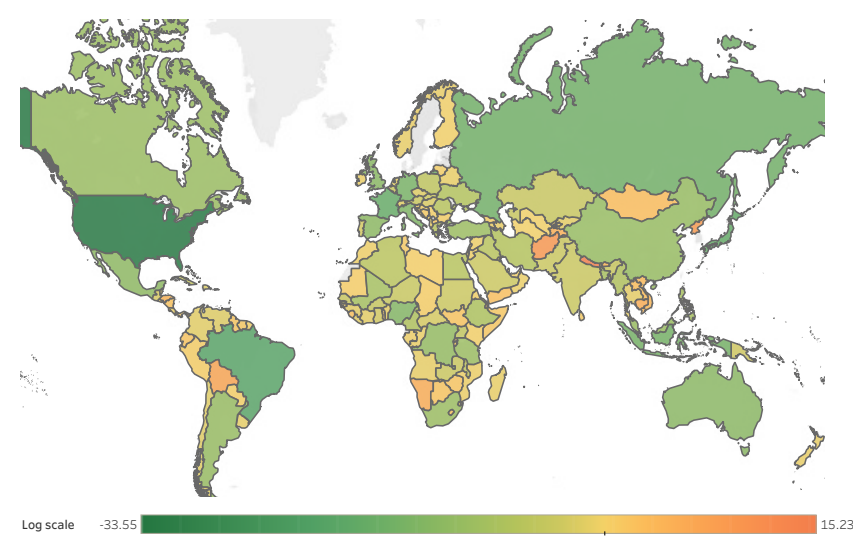

(c) Average death per capita; Flood

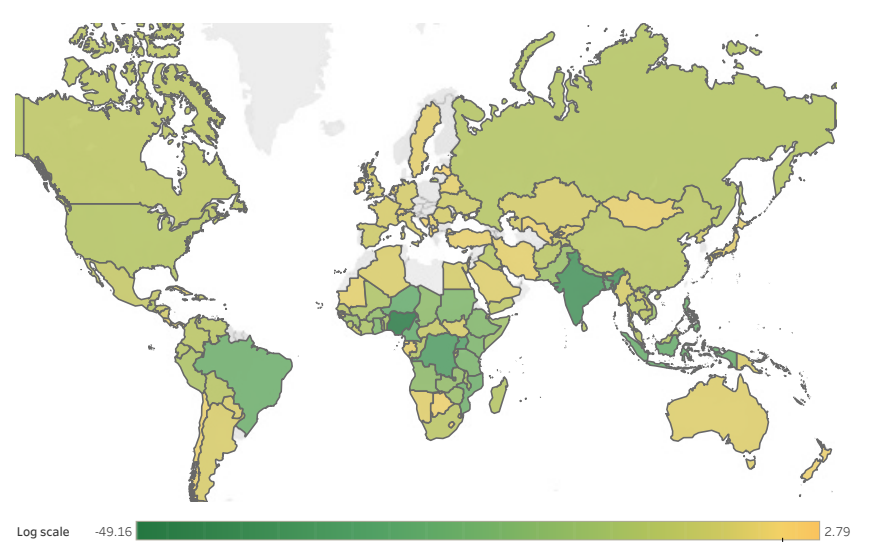

(b) Number of event per capita; Epidemic

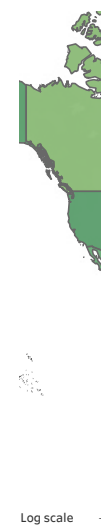

(d) Number of event per capita; Flood

Figure 6. Distribution of the flooding and pandemic events and the associated death during 1989-2019 worldwide, data are normalized by million people and presented in logarithmic scale; data source from EM-DAT (International Disaster Database) and visualized by A. Martinez; 27 May 2020.

In a separate experience, Ottawa, Canada, fights against spring flooding caused by melting snow were impacted by the COVID-19 outbreak. While trying to protect workers from the pandemic, another problem arose: there was a shortage of volunteers [40], which slowed down preparations for any potential hazards. The city government asked the public and organizations involved in reinforcing the city against flooding to follow COVID-19 guidelines and to conduct any work with less than five people.

Several weeks of torrential monsoon rains during June and July 2020 caused flooding and landslides in Bangladesh, Bhutan, India, and Nepal and killed over 700 people. According to July 2020 report by UNICEF, over 4 million children are estimated to be impacted and in urgent need of life-saving support. The COVID-19 pandemic made the situation complicated as the number of positive cases are accelerating in some of the affected areas. The compound hazard of the COVID-19 pandemic, climate change, and extreme weather 
events put many families in South Asia at risk. "The threat of COVID-19 adds challenges for our rescue and search teams", Nepal's National Emergency Operation Center chief said. Furthermore, it is not always possible to maintain the social distancing in the camps and this will spread the virus.

On 1 May 2020, after a long rainy week, part of an earth-fill dam broke along the Sardoba Reservoir in Uzbekistan and led to flooding the surrounding landscape. Figure 7 shows two images before and after flooding, taken by NASA's Terra satellite. According to AGU and The Diplomat, four people died, about fifty were injured, and 70,000 were evacuated from 22 villages in the affected area. This reservoir was completed in 2017, after seven years of construction. The reservoir, 29 meters deep, was designed to hold $922 \mathrm{Mm}^{3}$ of water [41]. The officials did not release any further report about the evacuation condition and sheltering people during COVID-19 outbreak.

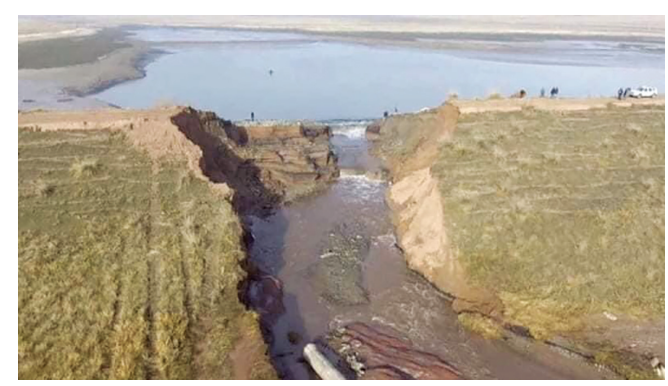

(a)
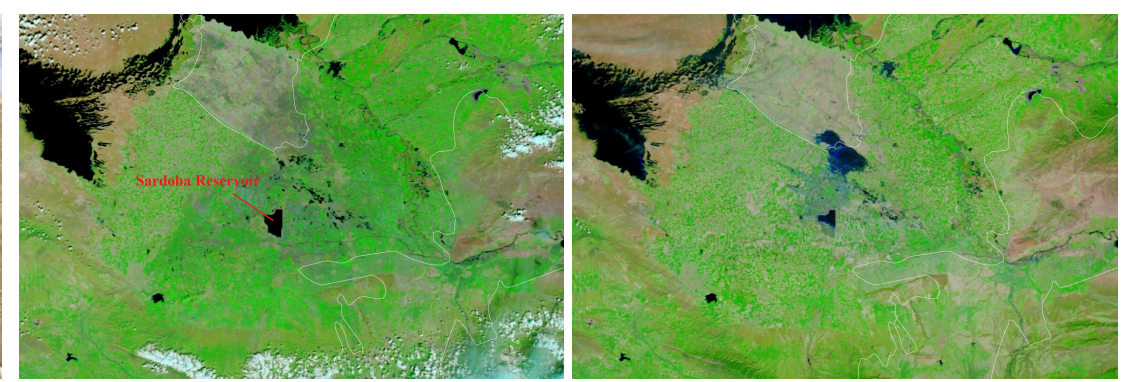

(b)

Figure 7. Uzbekistan dam failure; (a) Sardoba Dam failure on 1 May 2020; adopted from [42]; (b) Before (30 April 2020) and after (7 May 2020) dam break flooding; adopted from NASA Earth Observatory; flood water appears dark blue, saturated soil is light blue, vegetation is bright green, and bare ground is brown.

In the summer of 2020, there were multiple flash floods mainly in Southern Poland. In late July, there was $152 \mathrm{~mm}$ of rainfall over $24 \mathrm{~h}$ in Jodlownik. Simonovic et al. [38] reported a co-location of flood hazard and COVID-19 infection in South of Poland as the number of positive cases was consistently higher than in most other Polish provinces.

On 22 August 2020 the tropical storm Laura brought heavy rainfall to Haiti and Dominican Republic (with some locations recorded about $300 \mathrm{~mm}$ of rain in one day). Several rivers broke their banks, and several flooding were reported in Greater Santo Domingo. Civil Protection urged residents near the Artibonite River to evacuate their homes after flood gates of the Peligre Dam were opened [43].

On 16 September 2020 the Hurricane Sally made its way inland and killed at least one person in Alabama, U.S. According to NWS, the storm dumped about $760 \mathrm{~mm}$ and $630 \mathrm{~mm}$ of rain in Alabama and Florida, respectively. The rain has increased river levels, and as of September 18, the water levels were above moderate flood stage in multiple locations in these two states. The Shoal River in Florida reached above major flood stage. Nearly 500,000 homes and businesses lost power [43]. The authorities had some concerns about the developing pandemic. Hurricane Sally put a pause on COVID-19 testing because the sites were shut down for the week.

In fact, there was flooding all along the Mississippi, and the Mississippi River Cities and Towns Initiative (MRCTI), that represents over 100 towns and cities along the Mississippi river requested help with personal protective equipment (PPE) since they were unable to buy PPE on the market for first responders and emergency care workers. There was significant concern about COVID-19 exposure for the population during the flood fighting effort.

According to Reuters, on 18 July 2021 two dams in China's northwestern region of Inner Mongolia have collapsed after torrential rain. The combined reservoir capacity was about $46 \mathrm{Mm}^{3}$. People living downstream were evacuated, and no casualty was reported 
so far. About 17,000 people were affected in Hulunbuir city, several infrastructures have been destroyed.

Furthermore, Reuters reported that at least 25 died due to heavy rain and flooding in the central China's Henan province. According to NRP, on the 20 July 2021 the China's military has blasted the Yihetan Dam in the city of Luoyang to release floodwaters threatening a heavily populated area. Earlier that day, a $20 \mathrm{~m}$ breach occurred at the dam, and the riverbank was severely damaged due to flood. Since the COVID-19 situation is more or less under control in China (as of July 2021), no direct connect has been reported between dam failure, flooding and COVID-19 new infectious.

According to Science, beginning on 13 July 2021, an intense storm hit the Germany and Belgium. As of 17 July a total of 170 fatalities have been reported due to flash flood. A dam is collapsed in city of Wassenberg in the western Germany (along the river Rur) on 16 July 2021. About 700 residents in the Ophoven neighborhood were evacuated. Some other dams are also at the risk of failure. The Sun reported that about 4500 residents in villages near the Steinbach reservoir in North Rhine-Westphalia, Germany, were told to evacuate amid fears that the $57 \mathrm{ft}$ dam could collapse. The dam already overflowed and has deep furrows. At the time of publishing this paper, there was no report on the direct connection of flooding and the chance of spreading COVID-19. However, large scale evacuations, the potential interruption in COVID-19 testing centers, and involvement of many unvaccinated people in rescue procedure could cause superposed hazard.

All the above-discussed case histories show a strong connection between dam break or natural hazard induced flooding, relocation of people (i.e., evacuation and sheltering), and emergency need for extra PPE during the pandemic. This is, in fact, one of the motivations in this paper.

\subsection{Pandemic and Other Natural Hazards: Worldwide Experience}

As mentioned earlier, the concurrent effects of natural hazards and a pandemic outbreak can be studied from two perspectives:

- Occurs when a devastating natural hazard (e.g., flood, earthquake, hurricane) damages the fundamentals of health care system and consequently causes an outbreak in that region or country, i.e., an epidemic after a natural hazard event [44]. Here are a few examples of this kind of "double trouble":

- The 2004 South Asian tsunami hit sixteen countries, causing about 250,000 fatalities and displacing about 1.7 million people [45]. It later caused an acute respiratory infection outbreak in Indonesia [46].

- The 2010 magnitude 7.0 earthquake in Haiti caused about 200,000 fatalities and displaced about 1.5 million people [47]. It severely damaged the public health system and created an environment for potential outbreaks of infectious diseases [48]. About nine months later, a cholera outbreak began to spread across the country, killing about 8000 and infecting about 650,000 others. Prior to this devastating earthquake in 2010, there was no history of cholera in Haiti.

- Occurs when a natural hazard (not necessarily a devastating one) transpires during a pandemic outbreak. This may have an adverse effect on emergency resources, reducing the capability of the health system to help people and intensifying the spread of the infection through any means (e.g., evacuations into communal centers). We will focus on this category. Examples include:

- On 22 March 2020, an early morning earthquake with a moment magnitude of 5.3 hit the city Zagreb, Croatia [49]. The main shock was followed by numerous aftershocks, the strongest of which had a magnitude of 5.0 [50]. This resulted in one fatality, 27 injured, about 6200 damaged buildings, and over 1900 buildings became uninhabitable. COVID-19 testing was disrupted for hours in hospitals. While officials urged citizens, who left their homes, to keep socially distancing, some Zagreb residents disagreed with the order. "Earthquakes are more important 
than the coronavirus. If the earthquake hits, and you are under a door, you worry about yourself first and then the mask later," a man told a local TV station (See the Link). The earthquake caused a widespread panic making people leave their homes in hundreds of thousands, gravely compromising imposed social distancing [51].

- An early morning magnitude 5.1 earthquake hit Tehran, Iran, on 7 May 2020. The strongest aftershock had a magnitude of 3.9. At least two people died and about 38 were injured, though luckily there was no other major damage. According to the Reuters, officials urged people, some of whom spent the night outdoors for fear of aftershocks, to observe the social distancing mandated to prevent the spread of COVID-19.

To date, there is no solid reporting on the direct impacts of earthquakes on the spread of COVID-19 in Croatia or Iran; however, overlapping the incident day, as well as the 14-day incubation period, with daily variations in infection cases presents some increasing trends, which may or may not be coincidental, Figure 8. This appears clearer for the situation in Iran, as new cases of COVID-19 spiked after the number of people infected had been on the decline, though this may have been due to a second wave of the virus.

On the contrary, there are some reports that show minor impact of earthquake on the spread of COVID-19. Mavroulis et al. [52] post-processed publicly-available data on the daily reported laboratory-confirmed COVID-19 cases in Greece and correlated them with two earthquake events. They concluded that the impact of the Epirus earthquake (21 March 2020, magnitude 5.7) on the pandemic evolution in the northwestern part of Greece is negligible (only 2 out of 5 positive cases during post-earthquake period could be attributed to this shaking). They also found the impact of the Samos earthquake (30 October 2020, magnitude 6.9) on the COVID-19 speared in the eastern part of Greece is low (with only 12 reported positive cases). They did not find any relation between the 9 August 2020 Evia flood in the central Greece and increase in the number of COVID-19 cases.

- Between 12 and 13 April 2020, dozens of tornadoes tore through several U.S. states in the South. Homes were obliterated, and there were 36 fatalities. Many had to move to shelters, but one family was turned away at the door of a tornado shelter in Crossville, Alabama because the hopeful entrants did not have enough face masks for every member in their family [4].

- During August and September 2020, at least 35 people died in the U.S. West Coast wildfires, (24 in California, 10 in Oregon, and a child in Washington state), and tens of thousands were forced to evacuate their homes [53]. This implies COVID-19 related housing issues.

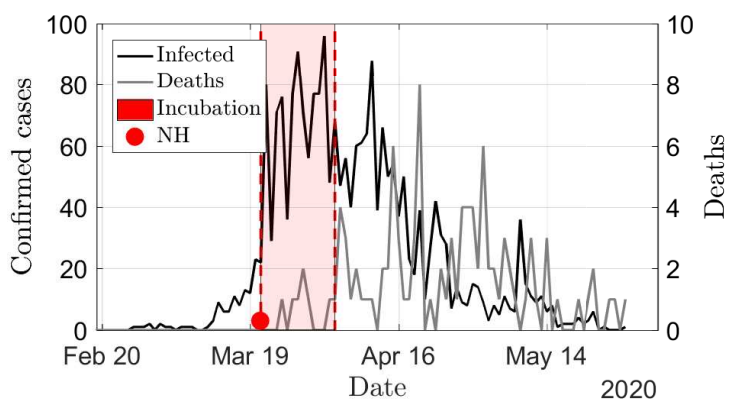

(a) Croatia

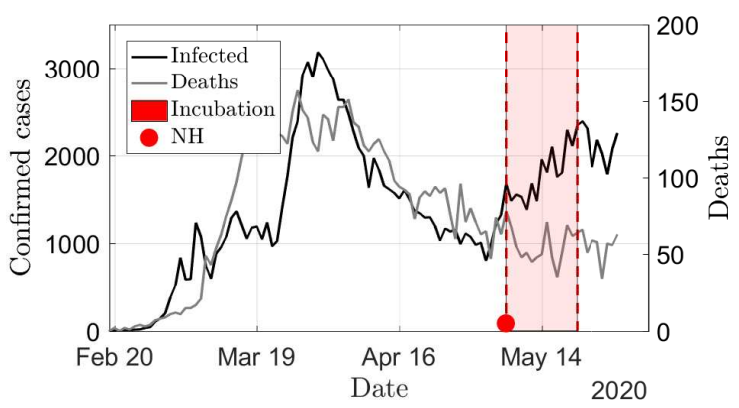

(b) Iran

Figure 8. Overlapping COVID-19 daily infection data [54] with occurrence of earthquake and 14-day incubation period. 


\section{Risk Assessment and Emergency Management Frameworks}

\subsection{Classical Risk-Informed Decision Making}

Risk-informed decision-making (RIDM) is a classic approach to safety decision making that asks this important question: "Are the existing risks tolerable and present risk measures adequate, and if not, are alternative risk reduction measures justified?" This widelyapproved framework for risk-based dam safety is shown in Figure 9. While the term "risk" refers to a measure of the probability and severity of an adverse effect to life, health, property, or the environment, ICOLD [55], in the context of dam safety, it is comprised of three elements:

- The likelihood of occurrence of a load (e.g., flood).

- The likelihood of an adverse structural response (e.g., dam break) given the load.

- The magnitude of the consequences given the event (e.g., loss of life) that occurs.

- Direct consequences are always estimated.

- Indirect consequences (e.g., downtime, destruction of property, and the displacement of people) are also estimated, where possible, and can be incorporated into the risk estimates.

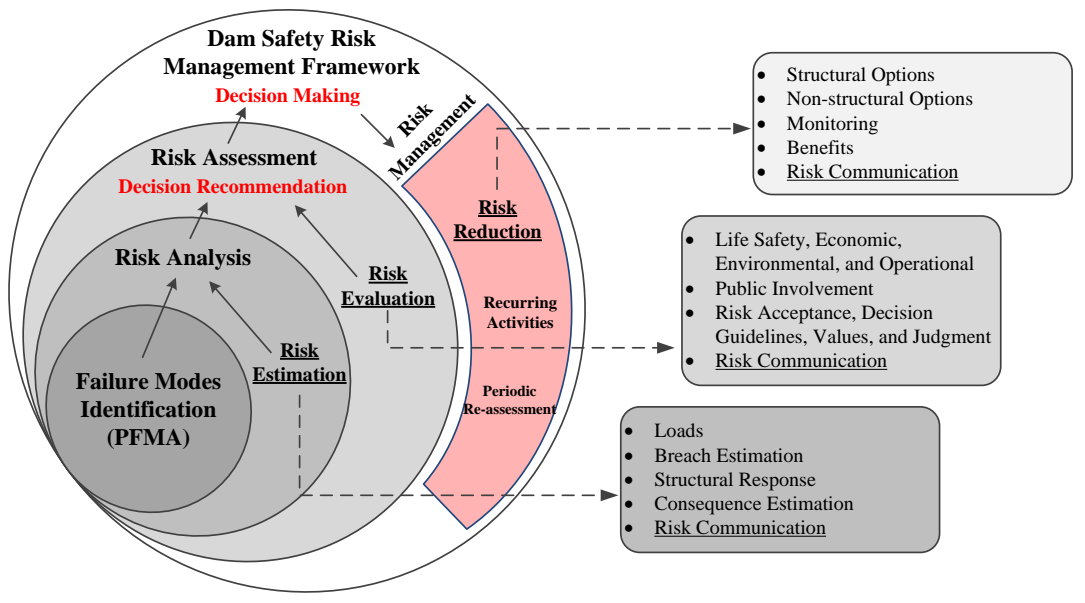

Figure 9. General framework of risk-based dam safety; adapted from [56].

Risk is evaluated in three categories [57]: (1) incremental risk—risk to the reservoir area and downstream floodplain occupants, (2) non-breach risk-risk to the reservoir area even if the dam does not fail, and (3) residual risk-risk to the reservoir area and downstream of the dam at any point in time. These three types can be combined with four types of risk measures: (1) life safety risk, (2) annual probability of failure (APF), (3) economic considerations, and (4) the environment and other non-monetary consequences.

\subsection{Pandemic-Centered Risk Assessment}

The policy during a pandemic is different from the policy during other natural hazard events [58]. An integrated policy is required for managing disasters during the pandemic [59]. Pandemics bring new elements and force decision makers to think outside the typical emergency management cycles. The four phases in natural hazard risk assessment (i.e., response, recovery, mitigation, and preparedness) are essentially linear. In the case of a pandemic, the response and recovery phases are nonlinear [58], Figure 10. A natural hazard, such as a flood, occurs in a limited timeframe and usually with only one peak (in the case of earthquakes, multiple after-shocks might occur within discrete time periods); however, a pandemic, e.g., COVID-19, tends to hit society in multiple waves over a relatively long period of time, until a cure or vaccine is discovered. Additionally, a natural hazard is usually limited to a bounded area or region. For example, a dam break flood affects the river or lake neighborhood and an earthquake shakes up the region to a specific distance 
along its wave propagation. A pandemic is different in that it can spread at national and global levels, if not controlled in a timely manner.

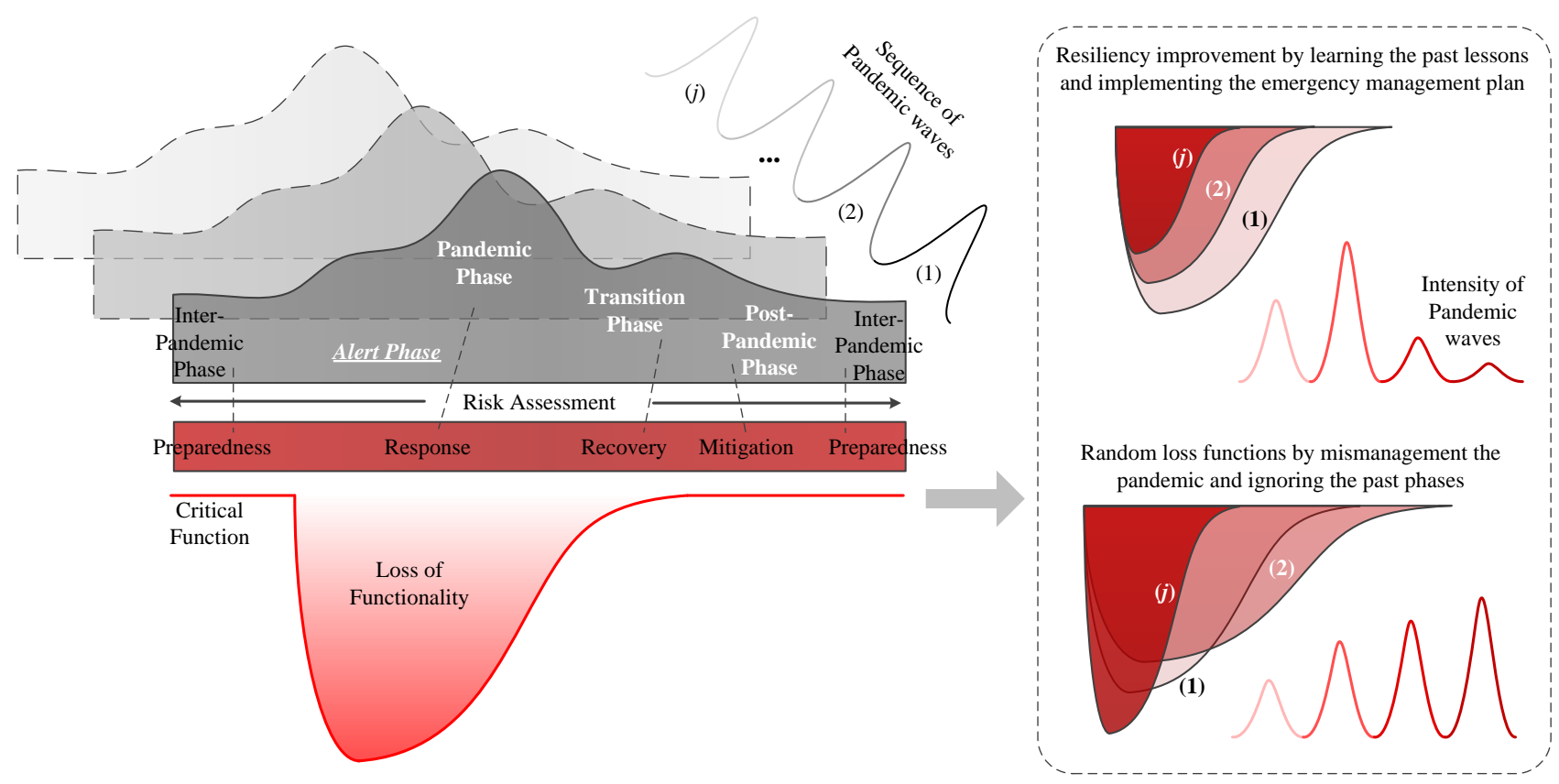

Figure 10. Risk assessment and emergency management plan for natural hazard and pandemic; adapted from [60] and extended.

Another important concern is that a large group of people remotely work because of the pandemic, or in some cases the city/region is under a lockdown order in response to the pandemic. In this condition, if a natural hazard occurs the first responders (which includes even the managers and scientists) may be away from where they are supposed to be in the normal condition. For example, a flooding may destroy the access roads or a bridge. As another example, the hurricane or earthquake may damage the telecommunication facilities or make it difficult to access the electronic resources on time. These issues and other similar ones need to be properly addressed during the planning and preparation phases. In a challenging experience, Pankow et al. [61] explained how they responded to the 2020 Magna, Utah, earthquake (the largest instrumentally recorded earthquake in the Salt Lake Valley) while the majority of Utah Seismograph Stations (UUSS) staff were working remotely.

According to Figure 10, the alert phase refers to when a novel pathogen has been identified in humans. The pandemic phase corresponds to a period of global spread of the disease. The inter-pandemic phase is the time between pandemics. As stated, pandemics come in multiple waves; since they are all distinct, the same policy approach cannot be applied to all cases. After each wave $j$, policies and protocols should be revised (i.e., the concept of Bayesian updating) to minimize negative consequences. A fast and efficient recovery from the adverse effects of a natural hazard or pandemic is studied under the resiliency concepts, which are not covered in this paper. It is important to minimize the loss of functionality, and updating the protocols and implementing the "lessons learned" helps to improve resiliency [10,62-67].

A summary of similarities and differences in the response and recovery phases of natural hazards versus pandemics is tabulated in Table 1 . One may note that even if both disasters share a similar element, the approaches to dealing with it are different for natural hazard events and pandemics. For example, the Early Warning System (EWS), discussed later in Section 4.1, is used for both but in different ways. 
Table 1. Similarities and differences of response and recovery phases in natural hazard (e.g., flooding) and pandemic (e.g., COVID-19); adopted from [58].

\begin{tabular}{|c|c|c|}
\hline Element & Natural Hazard & Pandemic \\
\hline \multicolumn{3}{|l|}{ Response } \\
\hline Conduct risk identification and assessment, early warning & $\checkmark$ & $\checkmark$ \\
\hline Establish emergency broadcast service for information dissemination & $\checkmark$ & \\
\hline Shorten decision-making process during emergency & $\checkmark$ & $\checkmark$ \\
\hline Establish temporary shelter and evacuation centers & $\checkmark$ & - \\
\hline Establish temporary testing sites, hospitals, and isolation facilities & - & $\checkmark$ \\
\hline Protect vulnerable people & $\checkmark$ & $\checkmark$ \\
\hline Establish data collection and monitoring system & $\checkmark$ & $\checkmark$ \\
\hline Provide financial and other support to those affected & $\checkmark$ & \\
\hline Control transboundary movements & - & $\checkmark$ \\
\hline Coordinate different sectors, including health, transportation, hospitality and others & $\checkmark$ & \\
\hline Coordinate research and development efforts & - & $\checkmark$ \\
\hline Establish online education and remote health care services & - & \\
\hline Develop economic response package & $\checkmark$ & $\checkmark$ \\
\hline Review and update legislation on surveillance & - & $\checkmark$ \\
\hline Develop exit (transition to recovery) strategies & - & $\checkmark$ \\
\hline Develop medical treatment and/or vaccines & - & \\
\hline \multicolumn{3}{|l|}{${ }^{1}$} \\
\hline Restore natural and man-made environment & $\checkmark$ & - \\
\hline Develop multi-level recovery framework & $\checkmark$ & $\checkmark$ \\
\hline Facilitate and ensure business continuity & $\checkmark$ & $\checkmark$ \\
\hline Ensure equality and inclusion of vulnerable groups in recovery efforts & $\checkmark$ & $\checkmark$ \\
\hline Clear debris from important nodes and paths & $\checkmark$ & - \\
\hline Reconstruct based on a safe building code and land use & $\checkmark$ & - \\
\hline Strengthen community capacity & $\checkmark$ & $\checkmark$ \\
\hline Provide mental health funding & $\checkmark$ & $\checkmark$ \\
\hline Monitoring and evaluation & $\checkmark$ & $\checkmark$ \\
\hline Develop strategies for new waves of disaster & - & $\checkmark$ \\
\hline
\end{tabular}

According to High-Level Experts and Leaders Panel on Water and Disasters [68], the competition and complications between disaster risk reduction (DRR) emergency responses and COVID-19 healthcare responses could magnify negative impacts in some countries and cities. Implementation of DRR strategies and preemptive actions are needed to protect areas impacted by water-related disasters from becoming new epicenters of the pandemic. They provide a series of principles to advise leaders and managers of DRR and COVID-19, as well as stakeholders, on how to prepare, respond, and mitigate the impacts of concurring disasters [68]:

- 'Enhance leaders' awareness on DRR in the pandemic.

- Integrate risk management of disasters and pandemics.

- Provide clean water, sanitation, and hygiene sustainably during and after disasters.

- Protect disaster risk management stakeholders from threat of COVID-19.

- Protect scarce medical resources from disaster impact.

- Protect disaster evacuees from threat of COVID-19.

- Protect COVID-19 patients from threat of disasters.

- Develop specialized evacuation guidance for cities and areas under COVID-19.

- Finance DRR actions under COVID-19 effectively to avoid economic catastrophe.

- Strengthen global solidarity and international cooperation to cope with these cooccurring challenges."

Ishiwatari et al. [69] recommends a series of policies for flood disaster management (not necessarily from a dam break) amid the COVID-19 pandemic:

- Integrate the concept of human security into new policy. 
- Put a priority on protecting human life at evacuation centers and of disaster management staff.

- Focus on the vulnerable groups.

- Engage local organizations and communities.

- Risk communication with scientific knowledge.

- Coordinate with multiple sectors, in particular, water and health.

\section{Elements of Classical Life Safety Risk}

Dam failures and associated flash floods can result in high fatality rates, especially when flooding overwhelms an unsuspecting group of people. Dam failures that produce slowly rising floods tend to result in lower fatality rates. Thus, there are two questions to be answered: How do you model potential loss of life? (addressed in Section 4.1)? What metric decides the loss of life risk (addressed in Section 4.2)?

\subsection{Loss of Life Models}

In general, the following considerations are required in order to estimate the loss of life from dam failure [70-73]:

Breach factors: cause and type of failure $\left(F_{t}\right)$, breach location $\left(L_{b}\right)$, breach geometry $\left(G_{b}\right)$, and development rate $\left(\gamma_{d}\right)$.

Hydraulic factors: water depth $\left(H_{w}\right)$, flow velocity $\left(V_{w}\right)$, flood-rise rate $\left(\gamma_{f}\right)$, wave $\left(W_{v}\right)$, water temperature $\left(T_{w}\right)$, flood duration $\left(t_{f}\right)$, debris in water $\left(D_{w}\right)$, flood severity $\left(S_{f}\right)$.

Area and building factors: area topography $\left(A_{p}\right)$, area usage $\left(A_{u}\right)$, building type $\left(B_{t}\right)$, number of building story $\left(B_{n}\right)$, building quality $\left(B_{q}\right)$, roads $\left(R_{d}\right)$, traffic situation $\left(S_{t}\right)$, traffic tools $\left(O_{t}\right)$.

Time and weather factors: warning time $\left(t_{w}\right)$, time of day $\left(t_{d}\right)$, time of week $\left(t_{w}\right)$, time of year $\left(t_{y}\right)$, holiday or festival $(h f)$, weather $(w h)$

Population factors: age $(a g)$, gender $(g e)$, physical state $\left(p_{s}\right)$, faith $(f a)$, experience/knowledge of flood $\left(e_{f}\right)$, family relationship $\left(f_{r}\right)$, financial state $\left(f_{s}\right)$, population distribution $\left(p_{d}\right)$, human decision $\left(d_{h}\right)$, human behavior $\left(b_{h}\right)$.

All of the proposed models include some level of natural- (e.g., depth of dam overtopping that causes failure) and knowledge-based uncertainties (e.g., breach shape, ultimate size) [74]. Different researchers have proposed a large variety of methods, including deterministic, probabilistic, and Bayesian. A review of the existing models for human risk analysis due to floods can be found in Jonkman [71]. Various software are also available to estimate loss of life, e.g., [75]; however, of the parameters mentioned, flood severity and warning time are the most crucial. According to the data collected and the suggested limits by the U.S. Bureau of Reclamation (USBR) [76], an adequate warning time may reduce the fatality rate by one to two orders of magnitude, Figure 11, as the at-risk population will have enough time to escape from high-hazard areas to safer shelters. This would also facilitate social distancing measures and allow people to avoid mass gatherings during a pandemic.

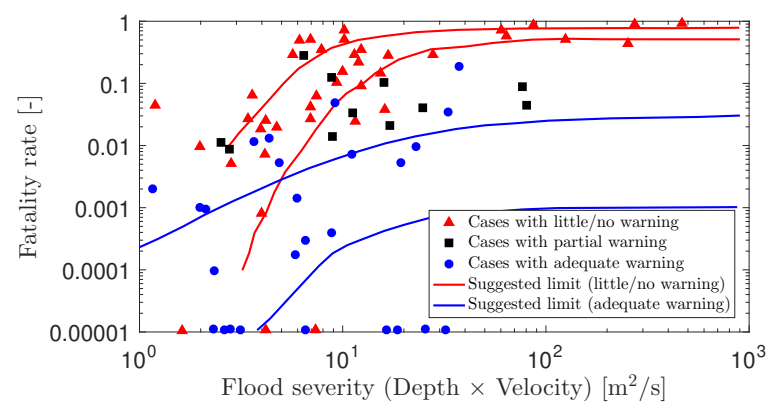

Figure 11. Fatality rate as a function of flood severity and warning time [76]. 
A safe evacuation plan during flood-pandemic multi-hazard is a vital task, and there are few studies addressing this important topic from different perspectives. Hariri-Ardebili [19] proposed a generic framework for regional-level and city-level evacuation and sheltering in pandemic era after a natural hazard. Tripathy et al. [77] proposed a multi-objective optimization framework for flood evacuation during pandemic by minimization of the evacuation risk. Maybe another important question is how to evacuate the high risk flood area, especially for the car-less population, elderly people, low income, of a racial minority, or with disabilities? Borowski et al. [78] discussed a series of sociodemographic (e.g., being female, under 36 years old, Black, or republican-identifying) and situational (e.g., households with children, social network proximity, and neighborly sharing attitudes) factors that contribute to a willingness to share flood evacuation rides with strangers during the pandemic. Their findings suggest that there is a correlation between higher levels of income, COVID-19 threat perception, evacuation fear, and household preparedness with a lower willingness to share rides.

It is noteworthy that the EWS used for natural hazards (in our case, a dam break) can be adopted, altered, and used for pandemics as well. Fearnley and Dixon [11] provided an interesting discussion for such a need in different countries. In New Zealand, for example, the COVID-19 Alert Level System [79] is composed of four color-coded alert levels: prepare, reduce, restrict, and lockdown. Each level has specific measures for public health, personal movement, and travel. In the U.S., similar epidemic EWSs have been advocated for using color-coded warnings based on the Homeland Security model [11].

\subsection{Loss of Life Metrics}

The incremental life safety risks proposed by FERC are widely used in the United States [56] (note that alternative methods can be found, for example, in [80]):

Individual incremental life safety risk using probability of loss of life for the identifiable person or group by location that is most at risk of loss of life due to dam break. It is computed from all exposure conditions and all potential failure modes (PFMs) associated with all loading or initiating events.

\section{Societal incremental life safety risk:}

- Probability distribution of potential loss of life is represented by a probability distribution of the estimated annual probability of potential loss of life from dam failure for all loading types and conditions, all PFMs, and all population exposure scenarios.

It is displayed in an F-N chart which is a plot of the cumulative frequency of incremental loss of life of $\mathrm{N}$ or more lives, $\mathrm{F}$, vs. incremental loss of life, $\mathrm{N}$, associated with the incremental flood risk, See Figure 12.

- Average annual life loss (AALL): The value of this metric for a dam should be estimated from all PFMs associated with all loading or initiating event types and considering all exposure conditions associated with loss of life. AALL is presented in an $f$-N chart. The estimated loss of life plotted on the horizontal scale is the weighted average incremental life loss, $\bar{N}$.

The non-breach life safety risk is also considered and plotted on the cumulative frequency distribution of potential loss of life (F-N) chart with the x-axis showing loss of life, N, from non-breach flood.

Various legislation/committee/societies have different (and sometime diverse) guidelines to quantify the risk severity. One of the widely-used risk guidelines for life safety is the FERC [56] requirements (FERC has no tolerable risk guideline for economic and environmental consequences). Detailed metric can be found in Appendix A. In Sections 5.1 and 5.2, we will present some multi-hazard perspectives on the factors towards updating the risk metrics in dam safety by including pandemic effects. 


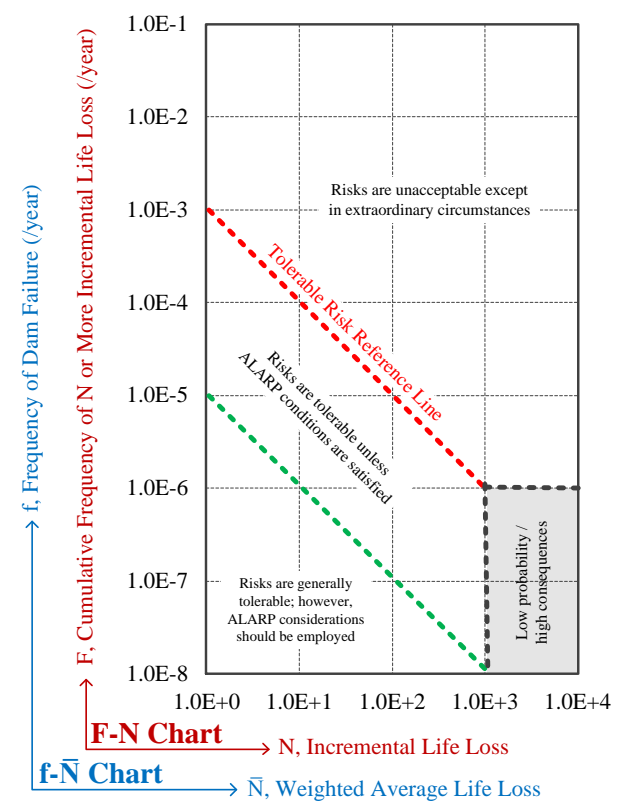

Figure 12. F-N and f-N̄ charts; adapted from [56].

\section{Pandemic as an Environmental Consequence}

While there exist some theories about the role of climate change in dam failure [81,82], some researchers compare the COVID-19 pandemic with climate change informed risk management [83-85]. Others provided general recommendations about potential association between environmental factors and COVID-19 [86,87].

During any natural hazard, rural areas are at risk due to the ongoing COVID-19 pandemic [88]. An improper response to flooding could increase the spread of COVID-19 and ultimately loss of life [69]. This is a two-sided problem: while response activities without social or physical distancing may spread COVID-19, extreme measures taken to lessen COVID-19 consequences could lead to inadequate responses to flood management, causing other negative effects.

A dam failure usually has both direct and indirect consequences that cannot be measured in monetary terms, such as impacts to environmental, cultural, and historic resources. People and the ecosystem might be exposed to hazardous or toxic materials released from landfills, warehouses, and other facilities. The sediment accumulated behind the dam is another source of hazardous material. These intangible consequences do not have directly observable physical dimensions, but they are important to take into account nonetheless:

- The grief and loss suffered by relatives and friends of those who die.

- The impact of multiple deaths on the psyche of the community in which they lived.

- The stress involved in arranging alternative accommodations and income.

- The sense of loss by those who enjoyed the natural landscape, which is destroyed.

- The fear of lost status and reputation of the dam owning/regulating organization(s) and their technical staff.

However, one low-probability, high-risk item that is usually left out of available dam break loss of life models is the impact of pandemic conditions. Following the classification of various relationships between pandemics and natural hazards (e.g., flooding) in Section 2.4, the concurrent intervention of these hazards can be studied from two perspectives:

- How might a flood occurrence affect the infection growth rate of COVID-19?

- How might the presence of COVID-19 adversely affect (i.e., increase) direct and indirect loss of life during a dam break flood? 


\subsection{Impact of Natural Hazard on Pandemic Growth Rate}

In order to properly respond to the first question, a short review of the pandemic growth dynamics is necessary. Most of the available (and widely-used) growth models are based on number of infections. The death number is proportionally related to it. Traditionally, the spread of a biological disease is modeled with an exponential growth as $[89,90]$ :

$$
\frac{d N(t)}{d t}=\lambda N(t)
$$

where $N(t)$ is the cumulative number of infections, and $\lambda>0$ is the growth rate. For an infinite supply of susceptible individuals, Equation (2) becomes $N(t)=\exp (\lambda t)$; while for the finite number of susceptible individuals, the model turns to be:

$$
\frac{d N(t)}{d t}=\lambda N(t)\left(1-\frac{N(t)}{K}\right)
$$

with $K=\lim _{t \rightarrow \infty} N(t)$ the final epidemic size. This equation has an explicit analytical solution as:

$$
N(t)=\frac{K}{1+\xi \exp (-\lambda t)} ; \quad \xi=\frac{K-N_{0}}{N_{0}}
$$

where $N_{0}$ is the initial infected population size. Figure 13a compares three growth models in which $k$ is set to $10,000, N_{0}$ is 1 , and $\lambda$ takes three values of $0.1,0.15$, and 0.2 . Clearly, the model with $\lambda=0.1$ has slowest growth (ideal case for societies since they can allocate enough medical services for all patients). Moreover, this case can be observed as a condition that quarantine conditions (as well as using face mask and keeping social distancing) is established by the society (compared to $\lambda=0.2$ case).

The growth rate $\frac{d N(t)}{d t}$ reaches the maximum when $\frac{d^{2} N(t)}{d t^{2}}=0$. Therefore, the growth rate peak occurs in time:

$$
t_{\text {peak }}=\frac{\ln \xi}{\lambda}
$$

A framework to incorporate natural hazard effects in pandemic growth rate is proposed below:

- We focus only on one "base case" (i.e., $\lambda=0.1$ ), and we call it the "pandemic only" scenario. It is assumed that no natural hazard occurs in this scenario.

- We assume that a natural hazard (i.e., flooding) occurs at some time before the inflection point, Equation (5), which is 92 in this case, Figure 13b. Note: The case with natural hazard after $t_{\text {peak }}$ is illustrated in Figure 13c.

- During this discussion, we do not address the direct loss of life due to a dam break flood. We only focus on the indirect fatality rate growth. The concept of mortality is used to connect the number of indirect fatalities, $N^{\prime \prime}$, to the total number of those affected, $N^{\prime}$ :

$$
\text { Mortality }=\frac{N^{\prime \prime}}{N^{\prime}}
$$

Jonkman [91] reports a worldwide mean mortality of 0.0355 and 0.0054 for flash and river floods, respectively. One should note that this value is highly dependent on the region or country and the infrastructure's maturity.

- According to the World Health Organization (WHO), COVID-19 has an incubation period of one to 14 days (with a median of five days). Therefore, we reflect the number of potential new patients in a linear mode from day one to 14 following the natural hazard. This is shown by the red curve in Figure 13b. The actual final increase at the end of day $14, N_{n h}$, should be obtained through continuous monitoring of all the people that are displaced after flooding. 
- In the most ideal—and maybe impossible — case, the number of those infected is not increased; however, if the number of infected people is potentially increased, three scenarios can be discussed:

- Scenario 1: There is no further action taken by society and/or the government, and thus the final number (estimated) of infected people, $N^{\prime}$, will be higher than $K+N_{n h}$ (sum of pandemic-only and natural hazard-induced cases). This is due to a sudden increase in the number of infected people, which increases the chance of spreading COVID-19.

- Scenario 2: Some restrictions are applied by society and/or the government to keep the growth rate similar to the "pandemic only" case. Therefore, $N^{\prime}$, will be equal to $K+N_{n h}$.

- Scenario 3: A severe level of restrictions is established by society and/or the government that is greater than during pandemic only conditions. In this scenario, the number of natural hazard-induced cases are dampened gradually, and the final $N^{\prime}$ will be equal to $K$. The impact of the pandemic is entirely absorbed by external activities.

A similar scenario can be discussed for cases when the natural hazard occurs after the inflection point. The only difference is that the rate of growth is already decreasing by that point and thus reaching an ideal scenario ( 2 or 3$)$ might be more feasible.

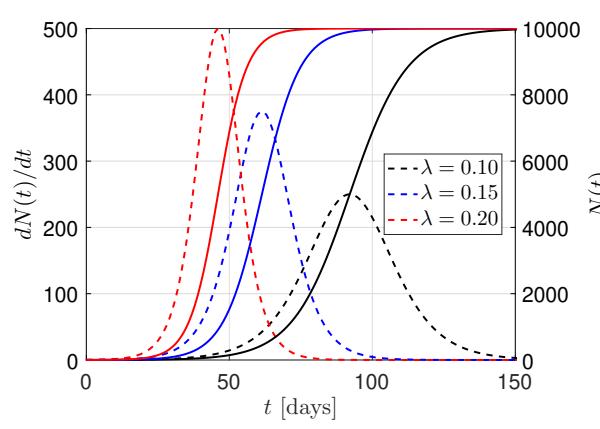

(a) Growth model

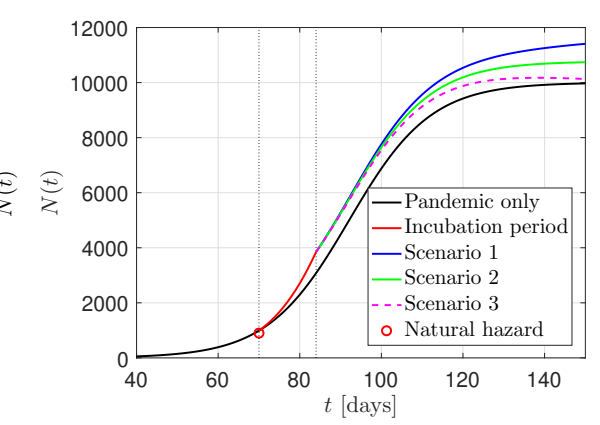

(b) Natural hazard occurrence before inflection point

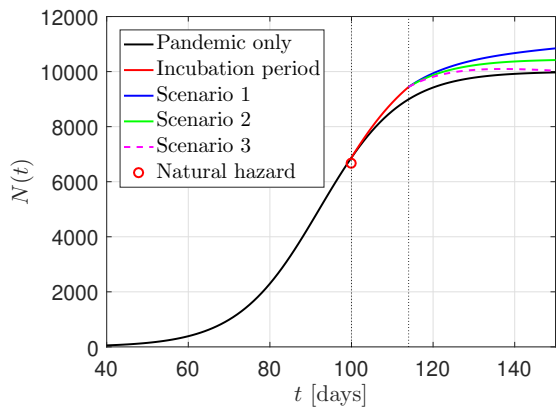

(c) Natural hazard occurrence after inflection point

Figure 13. Impact of a natural hazard occurrence on pandemic growth model.

\subsection{Impact of Ongoing Pandemic on Natural Hazard-Induced Loss}

While direct fatalities from a natural hazard are caused by the physical effects of the event, indirect fatalities are caused by unsafe or unhealthy conditions that occur because of the anticipation or actual occurrence of the disaster [91]. An indirect fatality outside the flooded area might originate from traffic accidents during evacuation or those due to post-flood stress, but the impact of an ongoing pandemic is not seen as a source of indirect fatalities. Therefore, following the FEMA [72]'s recommendations, one can add the pandemic parameter as a variable in which its true weight has not yet been investigated:

LoL Risk $=f($ Breach, Hydraulic, Area/Building, Time/Weather, Population, Pandemic $)$

During a flood, the downstream residents may move out of the disaster area and seek shelter on the upper floors of high buildings or evacuate the floodplains to natural highlands. The combined effect of "evacuation" and "sheltering" puts people at high risk of becoming infected (in this case with COVID-19) due to mass moves, gatherings, and a lack of sufficient social distancing. Shen et al. [92] conducted some preliminary research on combined effect of flooding-caused large population relocation and COVID-19 pandemic for the US. They claimed that there is a relation between the number of spatio-temporal flood insurance house claims and the displaced population. They also identified some areas 
within the US with higher risk of both flooding and COVID-19 (those area concentrated along the southern and eastern coasts and some parts of the Mississippi River).

The Centers for Disease Control and Prevention (CDC) and the World Health Organization $(\mathrm{WHO})$ recommend wearing face masks at all times during evacuations and socially distancing as much as possible. Thus, crowding a few hundred people into a high school gym may make things worse rather than better [93]. Moreover, the previous capacity limits of such facilities should be recalculated to account for social distancing practices, and mass gatherings should be avoided or reduced to the extent possible [94]. Subsequently, disaster preparedness is key during a pandemic, and the majority of this responsibility still falls on individuals, including having a "go kit" ready for emergencies with flashlights, bottled water, face masks, latex gloves, medications, hand sanitizers, soap, disinfectant wipes, and thermometers, etc. This brings our attention to the importance of evacuation drills as a key activity in preparing for an emergency due to a multi-hazard event (e.g., a natural hazard and a pandemic) [95]. Yet, we should not forget about mutual trust between individuals and the government/society [96] which yields to a successful emergency mission. In the case that the relief efforts are constrained due to pandemic, evacuation may be slower leading to more fatalities in the flooded areas.

"It would have been bad even with the best of government. Here it has been an absolute chaotic disaster" Barak Obama (9 May 2020).

Dincer and Gillanders [97] point out to an important issue about shelter in place and observing the social distancing. According to their findings, the communities in which corruption is endemic will find it difficult to employ effective containment and mitigation strategies based on social distancing. This may imply that the geographical location of dam break (i.e., which of the U.S. states) is also an important factor to be considered in this multi-hazard problem.

Any mass movement may cause spreading the virus. Mass gatherings during and after evacuations can be compared (not exactly in concept but nature) with gatherings during protesting. On 24 April 2020, a total of about 1500 people gathered at the State Capitol in Madison to protest. Two weeks later, the state Department of Health Services said there have been 1986 confirmed cases since the weekend of the rally. Of those, 72 people reported having attended a large gathering (people who tested positive were not asked specifically if they had attended the protest) [98]. Many of those in attendance did not maintain a six-foot distance from others or wear masks. Even assuming only 72 infectious in 1986 confirmed cases, it leads us to a ratio of 3.6\%. Prorating this ratio into 11,000 evacuees in Midland, one may estimate a total of about 400 infected people (in a similar condition of Madison; no serious social distancing or face covering). For more detailed information see Appendix $B$.

Although natural hazards occur in a finite period of time-from a few minutes in the case of earthquakes to a day or more in flooding events-their consequences might endure long enough to prevent people from coming back to their homes and following safe-at-home guidelines. This jeopardizes public health by giving more opportunities for COVID-19 to spread. Therefore, one important question is: How do you compare the risks of evacuating from a natural hazard with those of following or not following a stay-athome order enacted to prevent further infections? Though difficult to answer, the question depends on several factors, including the severity of natural hazard conditions, the level of pandemic outbreak, and the age and overall health of the people.

So far, the dam break scenario and its interaction with pandemic was studied at a lo$\mathrm{cal} /$ implicit level. However, some studies have shown the relation between the geographic hotspots and community drivers associated with spatial patterns in local transmission. Andersen et al. [99] investigated social, economic, and demographic determinants to spatial variation in COVID-19 across the U.S. and found that some locations with a greater proportion of a particular individuals (e.g., age, disability, language, race, occupation, and urban status) were associated with higher numbers of cases and deaths. This means that any potential natural hazard (e.g., flooding) in such locations may cause even more vulnerability. Therefore, the geographical location of the natural hazards should be explicitly considered 
in any hybrid pandemic-natural hazard risk model. In addition, the climatic condition of the site might affect the spread of the virus [100-102].

Flooding during a pandemic may cause another indirect loss by spreading the virus through the sewage overflows in the affected areas and communities. Han and He [103] discussed the sewage-associated transmission of COVID-19 on seven locations with high numbers of daily confirmed cases and flooding events (during May to August 2020). While they reported no conclusive trends, they highlighted the sewage overflows as a potential risk factor during a pandemic. The presence and transmission of COVID-19 genes in wastewater systems has been already proven [104-106].

Last but not least, mental health is also an important concern during pandemic outbreaks. Restrictive public health measures may have adverse effects on existing mental health disorders or create new stress-related disruptions. This may adversely affect people's reactions to a natural hazard and their decisions during a pandemic [107].

\section{Closing Remarks}

There is no doubt that the COVID-19 pandemic is one of the seven deadliest catastrophes to hit the U.S. over the last two decades. One may name these emergencies as the 9/11 terrorist attacks (2001), Hurricane Katrina (2005), the earthquake in Haiti (2010), the Deepwater Horizon oil spill (2010), the California firestorms (2015-2018), Hurricane Maria (2017), and the COVID-19 outbreak (2020). All of these hazards, and their subsequent disasters, highly affected the socioeconomical aspects of life. They caused large numbers of deaths, injured thousands, and displaced many others, some of whom never returned to their homes.

Communities and governments already understood the importance of preparedness for large-scale disasters, and many geneticists and researchers started to work on the concepts of "Hazard" and "Risk" to propose that a resilient community [108] and society could recover from adverse effects of a hazard in a fast, efficient way. Many went even further and discussed the concept of a multi-hazard environment on structural, social, and community levels [109]. Though various multi-hazard combinations have been discussed, including earthquakes, floods, hurricanes, fires, blasts, and even aging [110-112], the scenario of a concurrent natural hazard and pandemic/epidemic was nearly untouched. Therefore, an important question raised is: did we know about the importance of this problem beforehand, and could we predict such a condition in the future?

In December 2014 (and only a short time after the Ebola outbreak), the former President Barack Obama warned that the United States needed to prepare for an upcoming pandemic. In a speech (See the Link) to members of the National Institutes of Health, he emphasized the importance of building a public health infrastructure to combat the next pandemic, and he stressed the importance of preparedness:

"There may and likely will come a time in which we have both an airborne disease that is deadly, and in order for us to deal with that effectively, we have to put in place an infrastructure — not just here at home, but globally—that allows us to see it quickly, isolate it quickly, respond to it quickly, so that if and when a new strain of flu like the Spanish flu crops up five years from now or a decade from now, we've made the investment and we're further along to be able to catch it. It is a smart investment for us to make. It's not just insurance; it is knowing that down the road, we're gonna continue to have problems like this-practically in a globalized world, where you move from one side of the world to the other in a day. So this is important now, but it's also important for our future, and our children's future, and our grandchildren's future."

Thus, such an outbreak was predictable, yet the level of preparedness in the U.S., as well as most parts of the world, was not enough. While the main focus of this paper is life safety (as a metric), one should not forget about the social, economic, and even political aspects of a concurring natural hazard and pandemic outbreak. All of these elements are integrated together to build a pandemic-resilient community $[19,35,62-64,113]$ and improve its sustainability $[114,115]$. In the U.S., the unemployment rate increased from a constant 
rate of 3.5\% in February 2020 to 4.4\% in March, then suddenly spiked to 14.7\% in April, and it was back to $8.4 \%$ in August.

This urges us to move towards an integrated approach [58] to facing future pandemics with interdisciplinary science, combining medical sciences, biomedical science, social sciences, diplomacy, artificial intelligence and data analysis, information technology, engineering, statistics, meteorology, ecology, and so on, to provide an integrated cycle of prevention, preparation, response, and recovery.

The problem can become even more complicated by compound-hazard or multihazard conditions. The Midland dam failures not only forced thousands of citizens to relocate from their stay-at-home shelters into the social distancing challenges of mass shelters, but it also prompted a low-level emergency notification (NRC event \#54719) at a nearby nuclear research reactor [116]. Fortunately, no full-scale commercial nuclear reactor was in the path of the flood. If there had been a high-level risk associated with a nuclear reactor, it would have been almost impossible to safely evacuate thousands of people.

Worldwide, we have reported several flooding events during COVID-19 pandemic which led to evacuation and sheltering of thousands to millions of people. The events were occurred in the U.S., Canada, [China], [Japan], Bangladesh, Bhutan, Nepal, India, Uzbekistan, Haiti, Dominican Republic, and other places. Nearly all the accessible reports express medium to high level of concern about floods increasing risk of coronavirus spread. However, there was no solid research showing the direct loss of life due to interaction of flooding and pandemic. This can be attributed to the lack of the adequate measures to track such an interaction, as opposed to assuming a very good preparation for COVID-19 (for example, in some Asian countries affected by flooding during COVID-19, people do not even have access to clean drinking water).

Another important question which requires further study is to figure out if the recent experience with COVID-19 mitigation left the resources thin to address flood relief, or were the agencies already better prepared and organized and could therefore respond quickly? According to the director of the Midland County's health department (See the Link), about 260 people stayed in five emergency shelters at the night of flooding, and the public health officials, volunteers, and the Red Cross did all they could to mitigate the possibility of COVID-19 spreading inside the shelters (i.e., every person was screened for coronavirus symptoms, each had a temperature check, and they all received a face mask if they did not have one).

While we reviewed, reported, and answered several questions during this paper, many are left for further investigations:

In the case of multi-hazard, it is important to investigate in which condition one ends up with inadequate resources to deal with the next hazard? What are the dimensions of the supply chain that are most stressed? How can one best manage flood response if the communities do not have the ability to get basic supplies to address the pandemic? or How resilient are the societies when they are facing to multi-hazard? What are the limits of risk mitigation/resilience that are reasonable to expect local community investment in and what is needed at a larger scale?

Author Contributions: Conceptualization, M.A.H.-A. and U.L.; methodology, M.A.H.-A. and U.L.; formal analysis, M.A.H.-A.; investigation, M.A.H.-A. and U.L.; writing-original draft preparation, M.A.H.-A.; writing-review and editing, M.A.H.-A. and U.L.; visualization, M.A.H.-A. All authors have read and agreed to the published version of the manuscript.

Funding: This research received no external funding.

Institutional Review Board Statement: Not applicable.

Informed Consent Statement: Not applicable.

Data Availability Statement: Data are available from the corresponding author upon reasonable request. 
Acknowledgments: The authors would like to pay tribute and appreciation to all front-line workers who are fighting the COVID-19 pandemic. The first author also wishes to thank the following individuals for their help in improving the quality of this paper: Alexandre Martinez (UC Irvine) and Faraz Zorofchi (Formally Data Scientist at Aon) for preparing and visualizing some of the figures; and Amir M. Hariri-M.D. (ARUMS) for interpreting the epidemiological data.

Conflicts of Interest: The authors declare no conflicts of interest.

\section{Appendix A. Life Safety Risk Metrics}

For three types of incremental life safety risk guidelines:

Individual incremental life safety. The individual risk (IR) should meet the following criteria:

- If IR $\geq 1 \times 10^{-4}$ per year: risks are unacceptable except in extraordinary circumstances.

- If $1 \times 10^{-6} \leq \mathrm{IR}<1 \times 10^{-4}$ per year: risks are intolerable unless ALARP (refers to as low as reasonably practicable) conditions are satisfied.

- If IR $<1 \times 10^{-6}$ per year: risks are generally tolerable; however, ALARP considerations should be employed.

Societal incremental life safety as follows:

- Probability distribution of potential incremental life loss: the social incremental risk (SIR) should meet the following criteria and is evaluated based on the F-N chart, Figure 12:

- If SIR $\geq 1 \times 10^{-3}$ lives per year: SIR above the tolerable risk reference line is unacceptable except in extraordinary circumstances.

- If $1 \times 10^{-5} \leq \mathrm{IR}<1 \times 10^{-3}$ lives per year: SIR in this range will be considered intolerable unless ALARP considerations are satisfied.

- If SIR $<1 \times 10^{-5}$ per year: SIR in this range will be considered tolerable; however, the ALARP considerations should be employed.

- Low Probability/High Consequence region: If the estimated social risk falls into the gray zone in Figure 12, the evaluation of the tolerability of risk must be based on a thorough review of the project benefits and risks.

- Average Annual Life Loss: The AALL should meet the following criteria in accordance with f-N, Figure 12:

- If AALL $\geq 1 \times 10^{-3}$ lives per year: AALL in this range is unacceptable except in extraordinary circumstances.

- If $1 \times 10^{-5} \leq$ AALL $<1 \times 10^{-3}$ lives per year: AALL in this range will be considered intolerable unless ALARP considerations are satisfied.

- If AALL $<1 \times 10^{-5}$ per year: AALL in this range will be considered tolerable; however, the ALARP considerations should be employed.

- Low Probability/High Consequence region: If the estimated social risk falls into the gray zone in Figure 12, the evaluation of the tolerability of risk must be based on a thorough review of the project benefits and risks.

\section{Appendix B. Basic Reproduction Number}

It is noteworthy that the basic reproduction number, $R_{0}$, for COVID-19 is reported to be $2-4$ [117-119]. The $R_{0}$ can be thought of as the expected number of cases directly generated by one case in a population where all individuals are susceptible to infection [120]. The $R_{0}$ value for some other diseases is shown in Figure A1. According to this epidemiologic metric, when $R_{0}>1$ the infection will spread out in the population. The $R_{0}$ is defined as:

$$
R_{0}=\beta \times \tau
$$

where $\beta$ refers to infection-producing contacts per unit time, and $\tau$ is the mean infectious period. At the time of a natural hazard in the era of pandemic, Equation (A1) proposes two options to reduce the infection propagation, i.e., (1) reducing the number of contacts 
per unit time $\beta$ (e.g., staying at home or keeping physical distancing) or (2) decreasing the infectious period $\tau$ (e.g., isolation or short-term evacuations).

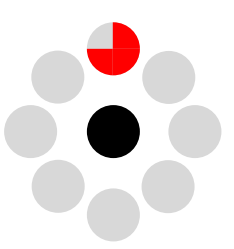

MERS

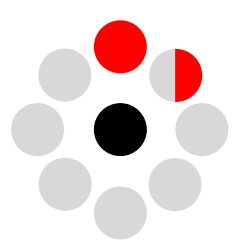

Influenza

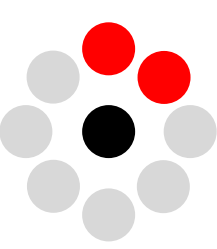

Ebola

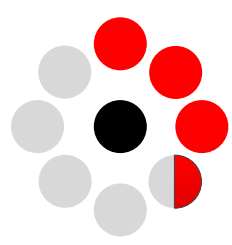

SARS

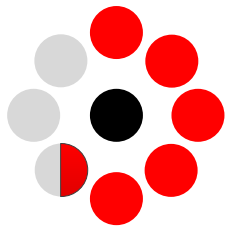

Mumps

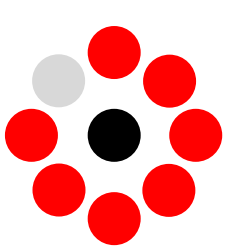

Rubella

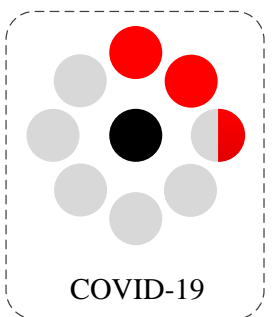

Figure A1. Comparison of basic reproduction number, $R_{0}$; adopted from Popular Science; 01 May 2021. Black and red circles present one sick person, and the number of infected persons, respectively.

\section{References}

1. Alexander, D. Natural Disasters; Routledge: London, UK, 2018.

2. Hariri-Ardebili, M. Risk, Reliability, Resilience (R3) and beyond in dam engineering: A state-of-the-art review. Int. J. Disaster Risk Reduct. 2018, 31, 806-831. [CrossRef]

3. FEMA. Federal Guidelines for Dam Safety Risk Management; Technical Report; Federal Emergency Management Agency: Washington, DC, USA, 2015.

4. Andrews, R. What Happens If a 'Big One' Strikes During the Pandemic? The Atlantic, 9 May 2020.

5. Sadegh, M.; Moftakhari, H.; Gupta, H.V.; Ragno, E.; Mazdiyasni, O.; Sanders, B.; Matthew, R.; AghaKouchak, A. Multihazard scenarios for analysis of compound extreme events. Geophys. Res. Lett. 2018, 45, 5470-5480. [CrossRef]

6. Tilloy, A.; Malamud, B.D.; Winter, H.; Joly-Laugel, A. A review of quantification methodologies for multi-hazard interrelationships. Earth-Sci. Rev. 2019, 196, 102881. [CrossRef]

7. Eshrati, L.; Mahmoudzadeh, A.; Taghvaei, M. Multi hazards risk assessment, a new methodology. Int. J. Health Syst. Disaster Manag. 2015, 3, 79.

8. World Health Organization. Coronavirus disease 2019 (COVID-19): Situation Report; World Health Organization: Geneva, Switzerland, 2020; 80.

9. Wu, Y.C.; Chen, C.S.; Chan, Y.J. The outbreak of COVID-19: An overview. J. Chin. Med. Assoc. 2020, 83, 217. [CrossRef] [PubMed]

10. Hellewell, J.; Abbott, S.; Gimma, A.; Bosse, N.I.; Jarvis, C.I.; Russell, T.W.; Munday, J.D.; Kucharski, A.J.; Edmunds, W.J.; Sun, F.; et al. Feasibility of controlling COVID-19 outbreaks by isolation of cases and contacts. Lancet Glob. Health 2020, 8, e488-e496. [CrossRef]

11. Fearnley, C.J.; Dixon, D. Early Warning Systems for Pandemics: Lessons Learned from Natural Hazards. I. J. Disaster Risk Reduct. 2020, 49, 101674. [CrossRef] [PubMed]

12. UNISDR. Sendai framework for disaster risk reduction 2015-2030. In Proceedings of the 3rd United Nations World Conference on DRR, Sendai, Japan, 14-18 March 2015; pp. 14-18.

13. Maini, R.; Clarke, L.; Blanchard, K.; Murray, V. The Sendai Framework for Disaster Risk Reduction and its indicators-where does health fit in? Int. J. Disaster Risk Sci. 2017, 8, 150-155. [CrossRef]

14. Thu, T.P.B.; Ngoc, P.N.H.; Hai, N.M. Effect of the social distancing measures on the spread of COVID-19 in 10 highly infected countries. Sci. Total Environ. 2020, 742, 140430. [CrossRef] [PubMed]

15. Valliappan, S.; Chee, C. Ageing Degradation of Concrete Dams Based on Damage Mechanics Concepts. In Computational Structural Engineering; Yuan, Y., Cui, J., Mang, H., Eds.; Springer: Cham, The Netherlands, 2009; pp. 21-35.

16. Bedford, J.; Farrar, J.; Ihekweazu, C.; Kang, G.; Koopmans, M.; Nkengasong, J. A new twenty-first century science for effective epidemic response. Nature 2019, 575, 130-136. [CrossRef]

17. Shi, W.; Hall, B.J. What can we do for people exposed to multiple traumatic events during the coronavirus pandemic? Asian J. Psychiatry 2020, 51, 102065. [CrossRef] [PubMed]

18. Mishra, A.; Bruno, E.; Zilberman, D. Compound natural and human disasters: Managing drought and COVID-19 to sustain global agriculture and food sectors. Sci. Total Environ. 2020, 754, 142210. [CrossRef] [PubMed]

19. Hariri-Ardebili, M.A. Living in a multi-risk chaotic condition: Pandemic, natural hazards and complex emergencies. Int. J. Environ. Res. Public Health 2020, 17, 5635. [CrossRef] [PubMed]

20. Haas, C. Coronavirus and risk analysis. Risk Anal. 2020, 40, 660-661. [CrossRef]

21. US Energy Information Administration. Electric Power Monthly. 2020. Available online: https://www.eia.gov/ (accessed on 15 May 2020).

22. Rich, Eddie Twitter Post. 2020. Available online: https://twitter.com/eddierich1?lang=en (accessed on 30 May 2020).

23. Editorial Team Hydropower and the impact of COVID-19. Water Power and Dam Construction, 18 May 2020. 
24. ASCE. 2021 Report Card for America's Infrastructure; Dams. American Society of Civil Engineers. 2021. Available online: https:/ / www.infrastructurereportcard.org/cat-item/dams/ (accessed on 30 March 2021).

25. National Performance of Dams Program. Dam Failures in the U.S., NPDP-01 V1; Technical Report; Department of Civil and Environmental Engineering, Stanford University: Stanford, CA, USA, 2018.

26. U.S. Department of the Interior, Bureau of Reclamation. DSO-99-06: A Procedure for Estimating Loss of Life Caused by Dam Failure; Technical Report; Dam Safety Office: Denver, CO, USA, 1999.

27. Graham, W.J. Major US dam failures: Their cause, resultant losses, and impact on dam safety programs and engineering practice. In Great Rivers History: Proceedings and Invited Papers for the EWRI Congress and History Symposium; American Society of Civil Engineers: Reston, VA, USA, 2009; pp. 52-60.

28. Zhang, L.; Xu, Y.; Jia, J. Analysis of earth dam failures: A database approach. Georisk 2009, 3, 184-189. [CrossRef]

29. ICOLD. ICOLD Incident Database Bulletin 99 Update: Statistical Analysis of Dam Failures; Technical Report; International Commission on Large Dams: Paris, France, 2019.

30. Hariri-Ardebili, M.A.; Salamon, J.; Mazza, G.; Tosun, H.; Xu, B. Advances in Dam Engineering. Infrastructures 2020, 5, 39. [CrossRef]

31. France, J.; Alvi, I.; Dickson, P.; Falvey, H.; Rigbey, S.; Trojanowski, J. Independent Forensic Team Report-Oroville Dam Spillway Incident; Technical Report; 2018. Available online: https://www.ussdams.org/our-news/oroville-dam-spillway-incidentindependent-forensic-team-final-report/ (accessed on 10 May 2020).

32. Brunner, G.W. HEC-RAS (river analysis system). In North American Water and Environment Congress \& Destructive Water; ASCE: New York, NY, USA, 2002; pp. 3782-3787.

33. NASA Earth Observatory Satellite. Muddy Flooding in Michigan. 2020. Available online: https://earthobservatory.nasa.gov / images/146752/muddy-flooding-in-michigan (accessed on 10 May 2020).

34. NID. National Inventory of Dams. 2019. Available online: https:/ / nid-test.sec.usace.army.mil/ords/f?p=105:22:13023978711032:: NO::: (accessed on 30 May 2020).

35. Litman, T. Pandemic-Resilient Community Planning: Practical Ways to Help Communities Prepare for, Respond to, and Recover from Pandemics and Other Economic, Social and Environmental Shocks. 2020. Available online: https://www.vtpi.org/PRCP.pdf. (accessed on 10 May 2020).

36. Osorio, C.; Williams, C.; Webber, T. Michigan flood displaces thousands, threatens Superfund site. ABC News, 21 May 2020.

37. FEMA P-946. Federal Guidelines for Inundation Mapping of Flood Risk Associated with Dam Incidents and Failures; Technical Report; Federal Emergency Management Agency: Washington, DC, USA, 2013.

38. Simonovic, S.P.; Kundzewicz, Z.W.; Wright, N. Floods and the COVID-19 pandemic-A new double hazard problem. Wiley Interdiscip. Rev. Water 2021, 8, e1509. [CrossRef]

39. Songsore, J. The complex interplay between everyday risks and disaster risks: The case of the 2014 cholera pandemic and 2015 flood disaster in Accra, Ghana. Int. J. Disaster Risk Reduct. 2017, 26, 43-50. [CrossRef]

40. Manitoba Government. High Water Response Activity: COVID-19 Adaptations, 2020. Available online: https://www.gov.mb.ca/ emo/pdfs/adaptations-to-high-water-response-activity.pdf (accessed on 30 May 2020).

41. Putz, C. 70,000 Evacuated after Breach in Uzbek Dam, Investigation into Failure Launched. The Diplomat, 4 May 2020.

42. Hydropower \& Dams. Investigations underway following Sardoba dam breach in Uzbekistan. Int. J. Hydropowers Dams 2020. https: / / www.hydropower-dams.com/news/investigations-underway-following-sardoba-dam-breach-in-uzbekistan/ (accessed on 30 May 2020).

43. Copernicus. Flood List. 2020. Available online: http:/ / floodlist.com/america (accessed on 29 September 2020).

44. Watson, J.T.; Gayer, M.; Connolly, M.A. Epidemics after natural disasters. Emerg. Infect. Dis. 2007, 13, 1-5. [CrossRef]

45. Ramalanjaona, G. Impact of 2004 tsunami in the islands of Indian ocean: Lessons learned. Emerg. Med. Int. 2011, 2011, 920813. [CrossRef]

46. Guha-Sapir, D.; van Panhuis, W.G. Health impact of the 2004 Andaman Nicobar earthquake and tsunami in Indonesia. Prehosp. Disaster Med. 2009, 24, 493-499. [CrossRef]

47. Doocy, S.; Cherewick, M.; Kirsch, T. Mortality following the Haitian earthquake of 2010: A stratified cluster survey. Popul. Health Metrics 2013, 11, 5. [CrossRef]

48. Houston, A.R. Applying Lessons from the Past in Haiti: Cholera, Scientific Knowledge, and the Longest-Standing Principle of International Health Law. In Infectious Diseases in the New Millennium; Springer: Cham, Switzerland, 2020; pp. 13-41.

49. Čivljak, R.; Markotić, A.; Capak, K. Earthquake in the time of COVID-19: The story from Croatia (CroVID-20). J. Glob. Health 2020, 10, e010349. [CrossRef] [PubMed]

50. Seismological Service of the Geophysical Department of the Faculty of Science. Short review of the earthquakes in the Zagreb area in the last two weeks (23 March-5 April 2020). 2020. (In Croatian) Available online: https://www.pmf.unizg.hr/geof/ seizmoloska_sluzba/o_zagrebackom_potresu_2020?@=1lqln\# (accessed on 30 May 2020).

51. Peitl, V.; Golubić Zatezalo, V.; Karlović, D. Mental Health Issues and Psychological Crisis Interventions during the COVID-19 Pandemic and Earthquakes in Croatia. Arch. Psychiatry Res. Int. J. Psychiatry Relat. Sci. 2020, 56, 193-198.

52. Mavroulis, S.; Mavrouli, M.; Lekkas, E. Geological and hydrometeorological hazards and related disasters amid COVID-19 pandemic in Greece: Post-disaster trends and factors affecting the COVID-19 evolution in affected areas. Saf. Sci. 2021, 138 , 105236. [CrossRef] 
53. BBC News. US West Coast fires in maps, graphics and images. BBC News, 18 September 2020. Available online: https: //www.bbc.com/news/world-us-canada-54180049 (accessed on 30 May 2020).

54. Roser, M.; Ritchie, H.; Ortiz-Ospina, E.; Hasell, J. Our World in Data-Mortality Risk of COVID-19. 2020. Available online: https:/ / ourworldindata.org/mortality-risk-covid (accessed on 30 May 2020).

55. ICOLD. Bulletin on Risk Assessment in Dam Safety Management; Technical Report; International Commission on Large Dams: Paris, France, 2005.

56. FERC. Risk-Informed Decision-Making (RIDM), Risk Guidelines for Dam Safety; Technical Report; Federal Energy Regulatory Commission: Washington, DC, USA, 2016.

57. USACE. Safety of Dams-Policy and Procedures; Technical Report EM 1110-2-1156; Department of the Army, U.S. Army Corps of Engineers: Washington, DC, USA, 2014.

58. Fakhruddin, B.; Blanchard, K.; Ragupathy, D. Are we there yet? The transition from response to recovery for the COVID-19 pandemic. Prog. Disaster Sci. 2020, 7, 100102. [CrossRef] [PubMed]

59. Ashraf, A. Lessons learned from COVID-19 response for disaster risk management. Nat. Hazards 2021, 107, 2027-2032. [CrossRef] [PubMed]

60. CDC. The Continuum of Pandemic Phases. 2016. Available online: https://www.cdc.gov/flu/pandemic-resources/planningpreparedness/global-planning-508.html (accessed on 30 May 2020).

61. Pankow, K.L.; Rusho, J.; Pechmann, J.C.; Hale, J.M.; Whidden, K.; Sumsion, R.; Holt, J.; Mesimeri, M.; Wells, D.; Koper, K.D. Responding to the 2020 Magna, Utah, earthquake sequence during the COVID-19 pandemic shutdown. Seismol. Soc. Am. 2021, 92, 6-16. [CrossRef]

62. Menoni, S.; Schwarze, R. Recovery during a crisis: Facing the challenges of risk assessment and resilience management of COVID-19. Environ. Syst. Decis. 2020, 40, 189-198. [CrossRef]

63. Hynes, W.; Trump, B.; Love, P.; Linkov, I. Bouncing forward: A resilience approach to dealing with COVID-19 and future systemic shocks. Environ. Syst. Decis. 2020, 40, 174-184. [CrossRef]

64. Keenan, J.M. COVID, resilience, and the built environment. Environ. Syst. Decis. 2020, 40, 216-221. [CrossRef]

65. Anderson, R.M.; Heesterbeek, H.; Klinkenberg, D.; Hollingsworth, T.D. How will country-based mitigation measures influence the course of the COVID-19 epidemic? Lancet 2020, 395, 931-934. [CrossRef]

66. San Lau, L.; Samari, G.; Moresky, R.T.; Casey, S.E.; Kachur, S.P.; Roberts, L.F.; Zard, M. COVID-19 in humanitarian settings and lessons learned from past epidemics. Nat. Med. 2020, 26, 647-648.

67. Van Bavel, J.J.; Baicker, K.; Boggio, P.S.; Capraro, V.; Cichocka, A.; Cikara, M.; Crockett, M.J.; Crum, A.J.; Douglas, K.M.; Druckman, J.N.; et al. Using social and behavioural science to support COVID-19 pandemic response. Nat. Hum. Behav. 2020, 4, 460-471. [CrossRef] [PubMed]

68. High-Level Experts and Leaders Panel on Water and Disasters (HELP). Principles to Address Water-related Disaster Risk Reduction (DRR) under the COVID-19 Pandemic. 2020. https:/ / www.wateranddisaster.org/principles-to-address-water-relateddisaster-risk-reduction-drr-under-the-covid-19-pandemic/ (accessed on 27 July 2021).

69. Ishiwatari, M.; Koike, T.; Hiroki, K.; Toda, T.; Katsube, T. Managing disasters amid COVID-19 pandemic: Approaches of response to flood disasters. Prog. Disaster Sci. 2020, 6, 100096. [CrossRef] [PubMed]

70. McClelland, D.M.; Bowles, D.S. Estimating Life Loss for Dam Safety Risk Assessment: A Review and New Approach; Institute for Water Resources: Alexandria, VA, USA, 2002.

71. Jonkman, S.N. Loss of Life Estimation in Flood Risk Assessment; Theory and Applications. Ph.D. Thesis, Civil Engineering and Geosciences, Delft, The Netherlands, 2007.

72. FEMA. Estimating Loss of Life for Dam Failure Scenarios; US Department of Homeland Security: Washington, DC, USA, 2011.

73. Peng, M.; Zhang, L. Analysis of human risks due to dam-break floods-Part 1: A new model based on Bayesian networks. Nat. Hazards 2012, 64, 903-933. [CrossRef]

74. Lee, J.S. Uncertainties in the predicted number of life loss due to the dam breach floods. KSCE J. Civ. Eng. 2003, 7, 81-91. [CrossRef]

75. Bowles, D.S.; Aboelata, M. Evacuation and life-loss estimation model for natural and dam break floods. In Extreme Hydrological Events: New Concepts for Security; Springer: Dordrecht, The Netherlands, 2006; pp. 363-383.

76. USBR. RCEM-Reclamation Consequence Estimating Methodology—Interim—Guidelines for Estimating Life Loss for Dam Safety Risk Analysis; Technical Report; U.S. Department of the Interior Bureau of Reclamation: Denver, CO, USA, 2015.

77. Tripathy, S.S.; Bhatia, U.; Mohanty, M.; Karmakar, S.; Ghosh, S. Flood evacuation during pandemic: A multi-objective framework to handle compound hazard. Environ. Res. Lett. 2021, 16, 034034. [CrossRef]

78. Borowski, E.; Cedillo, V.L.; Stathopoulos, A. Dueling emergencies: Flood evacuation ridesharing during the COVID-19 pandemic. Transp. Res. Interdiscip. Perspect. 2021, 10, 100352.

79. New Zealand Government. Unite against COVID-19 Alert System. 2020. Available online: https://covid19.govt.nz/alert-system (accessed on 30 May 2020).

80. Ge, W.; Qin, Y.; Li, Z.; Zhang, H.; Gao, W.; Guo, X.; Song, Z.; Li, W.; van Gelder, P. An innovative methodology for establishing societal life risk criteria for dams: A case study to reservoir dam failure events in China. Int. J. Disaster Risk Reduct. 2020, 49, 101663. [CrossRef] 
81. Lee, B.S.; You, G.J.Y. An assessment of long-term overtopping risk and optimal termination time of dam under climate change. J. Environ. Manag. 2013, 121, 57-71. [CrossRef] [PubMed]

82. Fluixá Sanmartín, J.; Altarejos García, L.; Morales Torres, A.; Escuder Bueno, I. Climate change impacts on dam safety. Nat. Hazards Earth Syst. Sci. 2018, 18, 2471-2488. [CrossRef]

83. Manzanedo, R.D.; Manning, P. COVID-19: Lessons for the climate change emergency. Sci. Total Environ. 2020, 742, 140563. [CrossRef]

84. Bostrom, A.; Bohm, G.; OConnor, R.E.; Hanss, D.; Bodi-Fernandez, O.; Halder, P. Comparative risk science for the coronavirus pandemic. J. Risk Res. 2020, 23, 902-911. [CrossRef]

85. Sheehan, M.C. Climate Change and Human Well-Being in the 2020s: Lessons from 2020. Int. J. Health Serv. 2021, 51, 281-286. [CrossRef]

86. Zambrano-Monserrate, M.A.; Ruano, M.A.; Sanchez-Alcalde, L. Indirect effects of COVID-19 on the environment. Sci. Total Environ. 2020, 728, 138813. [CrossRef]

87. Espejo, W.; Celis, J.E.; Chiang, G.; Bahamonde, P. Environment and COVID-19: Pollutants, impacts, dissemination, management and recommendations for facing future epidemic threats. Sci. Total Environ. 2020, 747, 141314. [CrossRef]

88. Ranscombe, P. Rural areas at risk during COVID-19 pandemic. Lancet Infect. Dis. 2020, 20, 545. [CrossRef]

89. Batista, M. Estimation of the final size of the second phase of coronavirus epidemic by the logistic model. medrxiv 2020. Available online: https: / www.medrxiv.org/content/medrxiv/early/2020/03/16/2020.03.11.20024901.full.pdf (accessed on 27 July 2021).

90. Singer, H. The COVID-19 pandemic: Growth patterns, power law scaling, and saturation. arXiv 2020, arXiv:2004.03859.

91. Jonkman, S. Loss of Life Caused by Floods: An Overview of Mortality Statistics for Worldwide Floods; DC1-233-6; TU Delft: Delft, The Netherlands, 2003.

92. Shen, X.; Cai, C.; Yang, Q.; Anagnostou, E.N.; Li, H. The US COVID-19 pandemic in the flood season. Sci. Total Environ. 2021, 755, 142634. [CrossRef]

93. Davis, J.A. Disaster Preparedness Key Amid Pandemic, 2020. Available online: https://www.sej.org/publications/ backgrounders/disaster-preparedness-key-amid-pandemic (accessed on 30 May 2020).

94. Ebrahim, S.H.; Memish, Z.A. COVID-19-the role of mass gatherings. Travel Med. Infect. Dis. 2020, 34, 101617. [CrossRef]

95. Santos-Reyes, J. Factors motivating Mexico City residents to earthquake mass evacuation drills. Int. J. Disaster Risk Reduct. 2020, 49, 101661. [CrossRef] [PubMed]

96. Seddighi, H. Trust in Humanitarian Aid From the Earthquake in 2017 to COVID-19 in Iran: A Policy Analysis. Disaster Med. Public Health Prep. 2020, 14, e7-e10. [CrossRef]

97. Dincer, O.C.; Gillanders, R. Shelter in Place? Depends on the Place: Corruption and Social Distancing in American States. Soc. Sci. Med. 2020, 269, 113569. [CrossRef]

98. VanEgeren, J. 72 COVID Positive After Attending Large Event; WMTV: Madison, WI, USA, 2020.

99. Andersen, L.; Harden, S.; Sugg, M.; Runkle, J.; Lundquist, T. Analyzing the Spatial Determinants of Local Covid-19 Transmission in the United States. Sci. Total Environ. 2020, 754, 142396. [CrossRef]

100. Iqbal, M.M.; Abid, I.; Hussain, S.; Shahzad, N.; Waqas, M.S.; Iqbal, M.J. The effects of regional climatic condition on the spread of COVID-19 at global scale. Sci. Total Environ. 2020, 739, 140101. [CrossRef] [PubMed]

101. Menebo, M.M. Temperature and precipitation associate with Covid-19 new daily cases: A correlation study between weather and Covid-19 pandemic in Oslo, Norway. Sci. Total Environ. 2020, 737, 139659. [CrossRef]

102. Zhu, L.; Liu, X.; Huang, H.; Avellán-Llaguno, R.D.; Lazo, M.M.L.; Gaggero, A.; Soto-Rifo, R.; Patiño, L.; Valencia-Avellan, M.; Diringer, B.; et al. Meteorological impact on the COVID-19 pandemic: A study across eight severely affected regions in South America. Sci. Total Environ. 2020, 744, 140881. [CrossRef] [PubMed]

103. Han, J.; He, S. Urban flooding events pose risks of virus spread during the novel coronavirus (COVID-19) pandemic. Sci. Total Environ. 2020, 755, 142491. [CrossRef]

104. Daughton, C.G. Wastewater surveillance for population-wide Covid-19: The present and future. Sci. Total Environ. 2020, 736, 139631. [CrossRef] [PubMed]

105. Poch, M.; Garrido-Baserba, M.; Corominas, L.; Perelló-Moragues, A.; Monclús, H.; Cermerón-Romero, M.; Melitas, N.; Jiang, S.C.; Rosso, D. When the fourth water and digital revolution encountered COVID-19. Sci. Total Environ. 2020, 744, 140980. [CrossRef] [PubMed]

106. Kumar, M.; Patel, A.K.; Shah, A.V.; Raval, J.; Rajpara, N.; Joshi, M.; Joshi, C.G. First proof of the capability of wastewater surveillance for COVID-19 in India through detection of genetic material of SARS-CoV-2. Sci. Total Environ. 2020, 746, 141326. [CrossRef] [PubMed]

107. Marko, C.; Andro, K.; Petrana, B. Stay home while going out-possible impacts of earthquake co-occurring with COVID-19 pandemic on mental health and vice versa. Brain Behav. Immun. 2020, 87, 82-83. [CrossRef]

108. Twigg, J. Characteristics of a Disaster-Resilient Community: A Guidance Note; Technical Report; Department for International Development (DFID): London, UK, 2007.

109. Kappes, M.S.; Keiler, M.; von Elverfeldt, K.; Glade, T. Challenges of analyzing multi-hazard risk: A review. Nat. Hazards 2012, 64, 1925-1958. [CrossRef]

110. Asprone, D.; Jalayer, F.; Prota, A.; Manfredi, G. Proposal of a probabilistic model for multi-hazard risk assessment of structures in seismic zones subjected to blast for the limit state of collapse. Struct. Saf. 2010, 32, 25-34. [CrossRef] 
111. Kameshwar, S.; Padgett, J.E. Multi-hazard risk assessment of highway bridges subjected to earthquake and hurricane hazards. Eng. Struct. 2014, 78, 154-166. [CrossRef]

112. Hariri-Ardebili, M.; Saouma, V. Single and multi-hazard capacity functions for concrete dams. Soil Dyn. Earthq. Eng. 2017, 101, 234-249. [CrossRef]

113. Bryce, C.; Ring, P.; Ashby, S.; Wardman, J. Resilience in the face of uncertainty: Early lessons from the COVID-19 pandemic. J. Risk Res. 2020, 23, 880-887. [CrossRef]

114. Hakovirta, M.; Denuwara, N. How COVID-19 redefines the concept of sustainability. Sustainability 2020, 12, 3727. [CrossRef]

115. Sharifi, A.; Khavarian-Garmsir, A.R. The COVID-19 pandemic: Impacts on cities and major lessons for urban planning, design, and management. Sci. Total Environ. 2020, 749, 142391. [CrossRef] [PubMed]

116. Gunter, P. U.S. Unprepared for Nuclear Accident During Pandemic, 2020. Available online: https:/ /www.commondreams.org/ newswire/2020/05/22/us-unprepared-nuclear-accident-during-pandemic (accessed on 30 May 2020).

117. Zhao, S.; Lin, Q.; Ran, J.; Musa, S.S.; Yang, G.; Wang, W.; Lou, Y.; Gao, D.; Yang, L.; He, D.; et al. Preliminary estimation of the basic reproduction number of novel coronavirus (2019-nCoV) in China, from 2019 to 2020: A data-driven analysis in the early phase of the outbreak. Int. J. Infect. Dis. 2020, 92, 214-217. [CrossRef] [PubMed]

118. Liu, Y.; Gayle, A.A.; Wilder-Smith, A.; Rocklöv, J. The reproductive number of COVID-19 is higher compared to SARS coronavirus. J. Travel Med. 2020. [CrossRef]

119. Ochoa, Y.C.; Sanchez, D.E.R.; Peñaloza, M.; Motta, H.F.C.; Méndez-Fandiño, Y.R. Effective Reproductive Number estimation for initial stage of COVID-19 pandemic in Latin American Countries. Int. J. Infect. Dis. 2020, 95, 316-318. [CrossRef] [PubMed]

120. Fraser, C.; Donnelly, C.A.; Cauchemez, S.; Hanage, W.P.; Van Kerkhove, M.D.; Hollingsworth, T.D.; Griffin, J.; Baggaley, R.F.; Jenkins, H.E.; Lyons, E.J.; et al. Pandemic potential of a strain of influenza A (H1N1): Early findings. Science 2009, 324, $1557-1561$. [CrossRef] [PubMed] 